\title{
A revision of the systematics and distribution of the damselfly genus Prodasineura Cowley, 1934 (Odonata: Zygoptera: Platycnemididae) in Vietnam with description of two new species
}

\author{
Quoc Toan PHAN ${ }^{1, *} \&$ Quoc Phu NGO ${ }^{2}$ \\ ${ }^{1,2}$ The Center for Entomology \& Parasitology Researches, Institute of Researches and Training of \\ Medicine, Biology \& Pharmacy, Duy Tan University, 3 Quang Trung, Da Nang, Vietnam. \\ *Corresponding author: pqtoan84@gmail.com; phanquoctoan1@duytan.edu.vn \\ 2Email: ngoquocphu@gmail.com; ngoquocphu1@duytan.edu.vn \\ ${ }^{1}$ urn:lsid:zoobank.org:author:9DBB241C-A070-45DF-A111-B7BDDB56EEEE \\ ${ }^{2}$ urn:lsid:zoobank.org:author:34581D77-1365-4D24-A1BF-EB791D08ABD5
}

\begin{abstract}
Eight species of the genus Prodasineura Cowley, 1934 are recorded from Vietnam, including two newly described species: Prodasineura lancastrei sp. nov. and P. kong sp. nov. from north and central Vietnam. All species recorded are illustrated, including figures of morphological structures, and distribution maps and keys to the males and females are provided. We consider the record of P. laidlawi (Forster in Laidlaw, 1907) a misidentification and exclude it here.
\end{abstract}

Keywords. Odonata, Prodasineura, kong, lancastrei, damselfly, new species, Vietnam.

Phan Q.T. \& Ngo Q.P. 2020. A revision of the systematics and distribution of the damselfly genus Prodasineura Cowley, 1934 (Odonata: Zygoptera: Platycnemididae) in Vietnam with description of two new species. European Journal of Taxonomy 650: 1-27. https://doi.org/10.5852/ejt.2020.650

\section{Introduction}

Damselflies of the genus Prodasineura Cowley, 1934 were placed in the family Protoneuridae before Dijkstra et al. (2014) rearranged its members into the family Platycnemididae following molecular phylogenetic research. These are very slender damselflies, the males are usually black, striped with blue, red or yellow. The pattern of the male synthorax and abdominal tip and the morphology of the appendages are diagnostic characters for species of this genus. The male cerci are hammer-like with a pointed apex; the paraprocts are broad at base and tapering abruptly to a rounded tip. Females of Prodasineura are similar in shape and thoracic colour pattern. In females, the posterior pronotal lobe of the prothorax is characteristically well developed and offers good diagnostic characters for their separation. These damselflies are usually found on slowly flowing water with a sandy bottom, near open streams in pristine, secondary forests or on small river branches in the lowlands.

Presently, there are 37 valid species of Prodasineura (Schorr \& Paulson 2019) with six having been documented from Vietnam: Prodasineura autumnalis (Fraser, 1922), P. coerulescens (Fraser, 1932), P. croconota Ris, 1916, P. doisuthepensis Hoess, 2007, P. laidlawi (Forster in Laidlaw, 1907) and 
P. hoffmanni Kosterin, 2015 (Do \& Dang 2007; von Ellenrieder et al. 2015; Kosterin 2016; Phan \& Dinh 2016; Phan \& Ngo 2019). Kompier (2019) also reported another species on his blog: P. verticalis Selys, 1860. In this paper, we describe two new species for the Vietnamese fauna from locations in central Vietnam, P. lancastrei sp. nov. from Pu Mat National Park of Nghe An Province and P. kong sp. nov. from Tan Hoa Commune, Minh Hoa District of Quang Binh Province and from the north, Bac Kan and Cao Bang Provinces and provide further information on the occurrence of $P$. verticalis from southern Vietnam. We have removed $P$. laidlawi from the Vietnamese fauna since we believe this specimen from Dinh Quan of Dong Nai Province in Asahina (1969) probably refers to a misidentified P. coerulescens (see the notes of $P$. laidlawi). We provide colour photos of the structures for all eight Vietnamese species, and include distribution maps and keys to the males and females.

\section{Material and methods}

Damselflies were collected and placed in a plastic envelope. Specimens were kept alive for 24 hours to remove their intestinal contents. Thereafter, they were treated in acetone for $6-8$ hours, then dried for 2-4 hours indoors. Each specimen was preserved in a square paper envelope accompanied by locality data.

All examined specimens used in this study (apart from the specimens collected by Tom Kompier) are deposited in the Zoological Collection of Duy Tan University, Danang, Vietnam.

Specimens were examined and photographed using Microscope Zeiss Stemi 508 with camera Axiocam Erc 5s.

The distribution of each species is based on the records of examined specimens and field observations by the authors and T. Kompier (in litt.), as most species are distinctive and easily identified. The distribution maps (unless otherwise stated) are made by using Adobe Photoshop version 7.0.

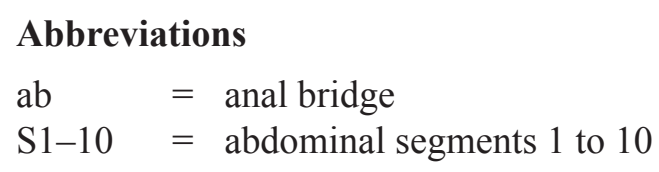

\section{Institutional abbreviations}

$\mathrm{RMNH}=$ Tom Kompier's collection at Naturalis Biodiversity Center, Leiden, The Netherlands

TKC $=$ Personal collection of Tom Kompier, The Netherlands

ZCDTU $=$ Zoological Collection of Duy Tan University, Danang, Vietnam

\section{Results}

Order Odonata Fabricius, 1793

Suborder Zygoptera Selys, 1854

Superfamily Coenagrionoidea Kirby, 1890

Family Platycnemididae Yakobson \& Bianchi, 1905

Subfamily Disparoneurinae Fraser, 1957

Genus Prodasineura Cowley, 1934

Prodasineura autumnalis (Fraser, 1922)

Figs $1 \mathrm{~A}-\mathrm{G}, 5 \mathrm{~A}-\mathrm{B}, 16 \mathrm{~B}-\mathrm{D}, 17$

\section{Material examined}

VIETNAM - Quang Nam Province • 1 đ, 1 + ; Tay Giang District, Bhalee Commune; 27 May 2015;

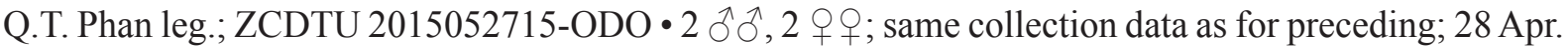


2018; Q.T. Phan leg.; ZCDTU 2018042817-ODO. - Binh Thuan Province • 2 ふ̊̊̊; Ham Thuan Bac District, Dong Tien Commune; 10 Oct. 2015; Dang Ngoc Van leg.; ZCDTU 201510102-ODO. - Lam Dong Province • 2 q $q$; Bao Loc District; 11 Mar. 2016; Q.T. Phan leg.; ZCDTU 2016031107-ODO. -

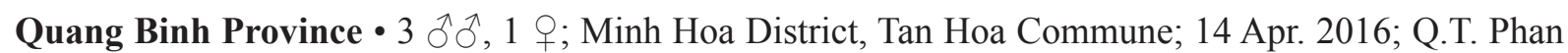
leg.; ZCDTU 2016041415-ODO. - Da Nang City • 1 ภ, 1 \%; Lien Chieu District, Lang Van; 21 Feb. 2017; Q.T. Phan leg.; ZCDTU 2017022101-ODO. - Dak Lak Province • 5 đ̊̊, 3 q $q$; Chu Yang Sin National Park; 30 Apr. 2017; Hoang Quang Duy leg.; ZCDTU 2017043021-ODO. - Nghe An Province - 2 ○̊ં; Con Cuong District, Mon Son Commune; 12 May 2019; Q.T. Phan leg.; ZCDTU 2019051234ODO.
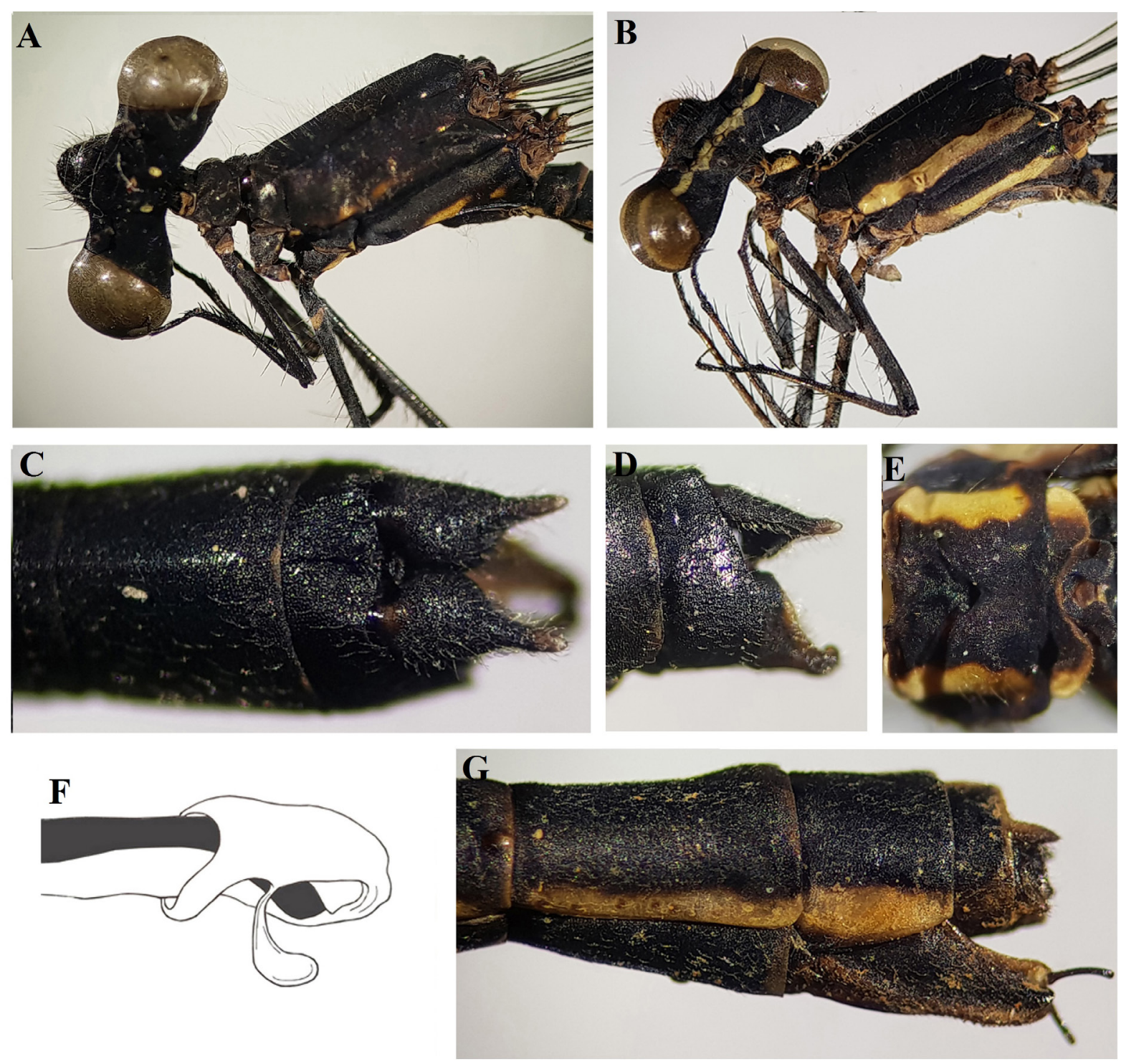

Fig. 1. Prodasineura autumnalis (Fraser, 1922), ZCDTU 2017043021-ODO. A. Oै, head and thorax, lateral view. B. ㅇ, head and thorax, lateral view. C. Appendages, dorsal view. D. Appendages, lateral view. E. , , prothorax, dorsal view. F. Genital ligula, oblique-ventral view. G. $ᄋ$, tip of abdomen, lateral view. Images not to scale. 


\section{Diagnosis}

Male characterized by black body with some pale markings on mesepisterum, metepimeron of synthorax (Fig. 1A-B) which disappear when reaching maturity; abdomen, appendages entirely black (Fig. 1C-D). Females similar to other species of genus in appearance. Prothorax black with two lateral yellow stripes extending to lateral margin of posterior pronotal lobe (Fig. 1E). Posterior pronotal lobe of prothorax strongly curved upward in lateral view, posteriorly bearing two converging processes (Fig. 5A). Abdomen black except for thin lateral whitish stripe running from S1 to S9 (Fig. 1G).

\section{Distribution}

Vietnam (Fig. 17): Cao Bang (Na Hang, Kim Dong and Thach An), Lang Son (Huu Lien Nature Reserve and Mau Son Mountain), Yen Bai (Tu Le), Bac Kan, Bac Giang, Phu Tho (Xuan Son National Park), Thai Nguyen, Vinh Phuc (Tay Thien and Tam Dao National Park), Hanoi (Ao Vua and Ba Vi National Park), Ninh Binh (Cuc Phuong National Park), Nghe An (Pu Mat National Park), Ha Tinh (Hong Linh Town, Huong Son and Huong Khe Districs), Quang Binh (Truong Xuan District), Quang Tri, Thua Thien-Hue (Bach Ma National Park and A Luoi Nature Reserve), Quang Nam (Cu Lao Cham Islands, Tay Giang and Nam Giang Districs), Da Nang (Ba Na and Son Tra Nature Reserves), Gia Lai (K'Bang District), Kon Tum (Chu Mom Ray National Park), Dak Lak (Chu Yang Sin National Park), Lam Dong (Bao Loc, Da Lat and Bidoup-Nui Ba National Park), Khanh Hoa (Hon Ba Nature Reserve), Dong Nai (Dinh Quan District), Binh Duong (Vo Dat), Binh Phuoc (Bu Gia Map National Park) and Tay Ninh (Ba Den mountain) Provinces (Do \& Dang 2007; T. Kompier pers. comm.; this study).

Prodasineura coerulescens (Fraser, 1932)

Figs 2A-B, 3A-B, E, 4A-C, 5D-E, 16C, 17

\section{Material examined}

VIETNAM - Dong Nai Province • 3 ồ $\widehat{O}, 3$ q $q$; Dinh Quan District, Mai waterfall; 8 Oct. 2016; Q.T. Phan leg.; ZCDTU 2016100801-ODO. - Quang Binh Province • 2 ふふ ; Minh Hoa District, Tan Hoa Commune; 18 Nov. 2019; Q.T. Phan \& Q.P. Ngo leg.; ZCDTU 2019111801-ODO.

\section{Diagnosis}

Male black with bluish stripes on head, thorax, abdomen and anal appendages (Figs 2A, 3A-B). S8 with two small distinct spots (in Dong Nai specimens, Fig. 3A) or entire dorsal stripe which extends posteriorly (in Quang Binh specimens); blue marking covering most of S9, gradually narrowing at base thus forming blue triangular-shaped spot; dorsal S10 blue, lateral-ventral black (Fig. 3A). Cerci dorsally entirely blue; paraproct blue, black apically (Fig. 3A-B). Female similar to male in shape, body colouration; pale elements are yellowish (Fig. 2B). Posterior pronotal lobe of prothorax with separate ear-like process on each side (Figs 4B, 5D-E).

\section{Distribution}

Vietnam (Fig. 17): Quang Binh (Minh Hoa District) and Dong Nai (Dinh Quan District and Cat Tien National Park) Provinces (Do \& Dang 2007; Kompier 2019; this study).

Prodasineura doisuthepensis Hoess, 2007

Figs 2C-D, 3C-D, F, 4D-F, 5C, 16A, 17

\section{Material examined}

VIETNAM - Kon Tum Province 1 đ̧; Kon Plong District, Mang Canh; 22 Sep. 2015; Q.T. Phan leg.; ZCDTU 2015092201-ODO • 4 ふ̂̉, 1 क; Chu Mom Ray National Park; 22 Jun. 2017; Q.T. Phan 
leg.; ZCDTU 2017062201-ODO. - Dak Lak Province • 1 ふै; Chu Yang Sin National Park; 18 May 2018; Q.T. Phan leg.; ZCDTU 2018051801-ODO. - Gia Lai Province • 8 đ̊̊̆; K’Bang District, Dak Roong Commune; 24 May 2018; Q.T. Phan leg.; ZCDTU 2018052410-ODO • 3 ふ̋ District, Ko Roong Commune, Ka Pang stream; 28 Jun. 2019; Q.T. Phan and Q.P. Ngo leg.; ZCDTU 2019062810-ODO.
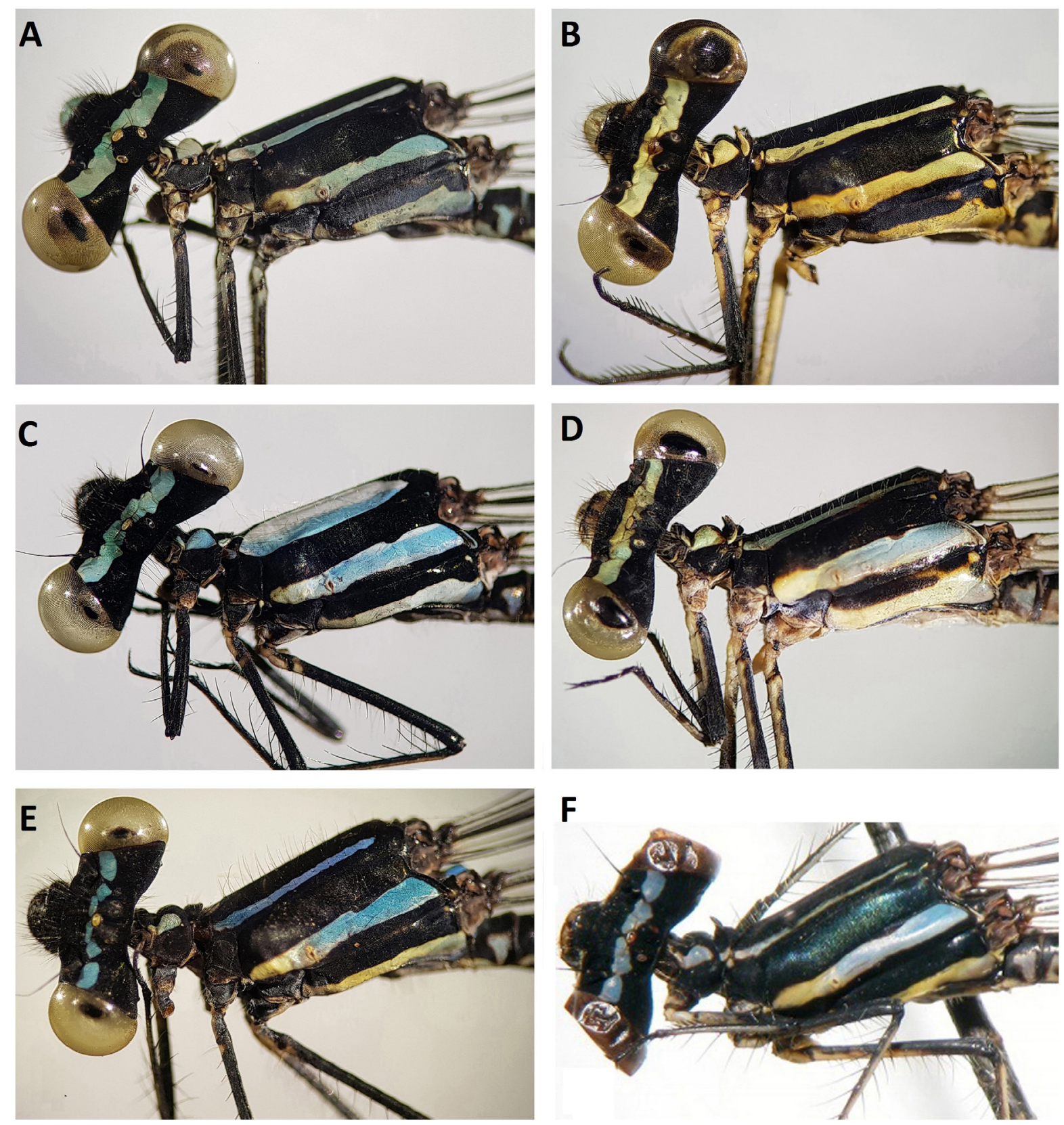

Fig. 2. Prodasineura Colwey, 1934 spp., head and thorax, lateral view (A, C, E: đ, B, D, F: P) A-B. P. coerulescens (Fraser, 1932), ZCDTU 2016100801-ODO. C-D. P. doisuthepensis Hoess, 2007, ZCDTU 2017062201-ODO. E-F. P. hoffmanni Kosterin, 2015, ZCDTU 2017062202-ODO (E). Fig. 2F is modified from Kosterin (2015: fig. 2a), from Dak Dam village, Mondulkiri Province, Cambodia. Images not to scale. 


\section{Diagnosis}

Male distinctive with large blue oval markings on mesepisterum (Fig. 2C); dorsum of S9 with rounded blue spot (Fig. 3C), versus only very small blue dot in P. hoffmanni (Fig. 3G) or large marking on S9, two smaller dots or stripe on S8 in P. coerulescens (Fig. 3A). Posterior pronotal lobe of female prothorax similar to that in $P$. hoffmanni, with short horn on each side, two rounded processes posteriorly; lobes not converging (Figs 4D-E, 5C).

\section{Distribution}

Vietnam (Fig. 17): Gia Lai (K'Bang District), Kon Tum (Chu Mom Ray National Park and Kon Plong District), Dak Lak (Chu Yang Sin National Park), Lam Dong (Bao Loc District), Khanh Hoa (Hon Ba Nature Reserve) and Dong Nai (Cat Tien National Park) Provinces (Kompier 2019; Phan \& Ngo 2019; this study).

Prodasineura hoffmanni Kosterin, 2015

Figs 2E-F, 3G-I, 4G-H, 5F, 16D, 17

\section{Material examined}

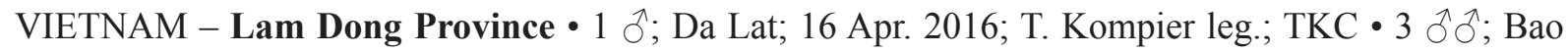
Loc, Da Ton; 22 Apr. 2016; Q.T. Phan leg.; ZCDTU 2016042210-ODO. - Kon Tum Province • 3 ô $\delta$; Kon Plong District, Mang Canh; 22 Jun. 2017; Q.T. Phan leg.; ZCDTU 2017062202-ODO. - Dak Lak
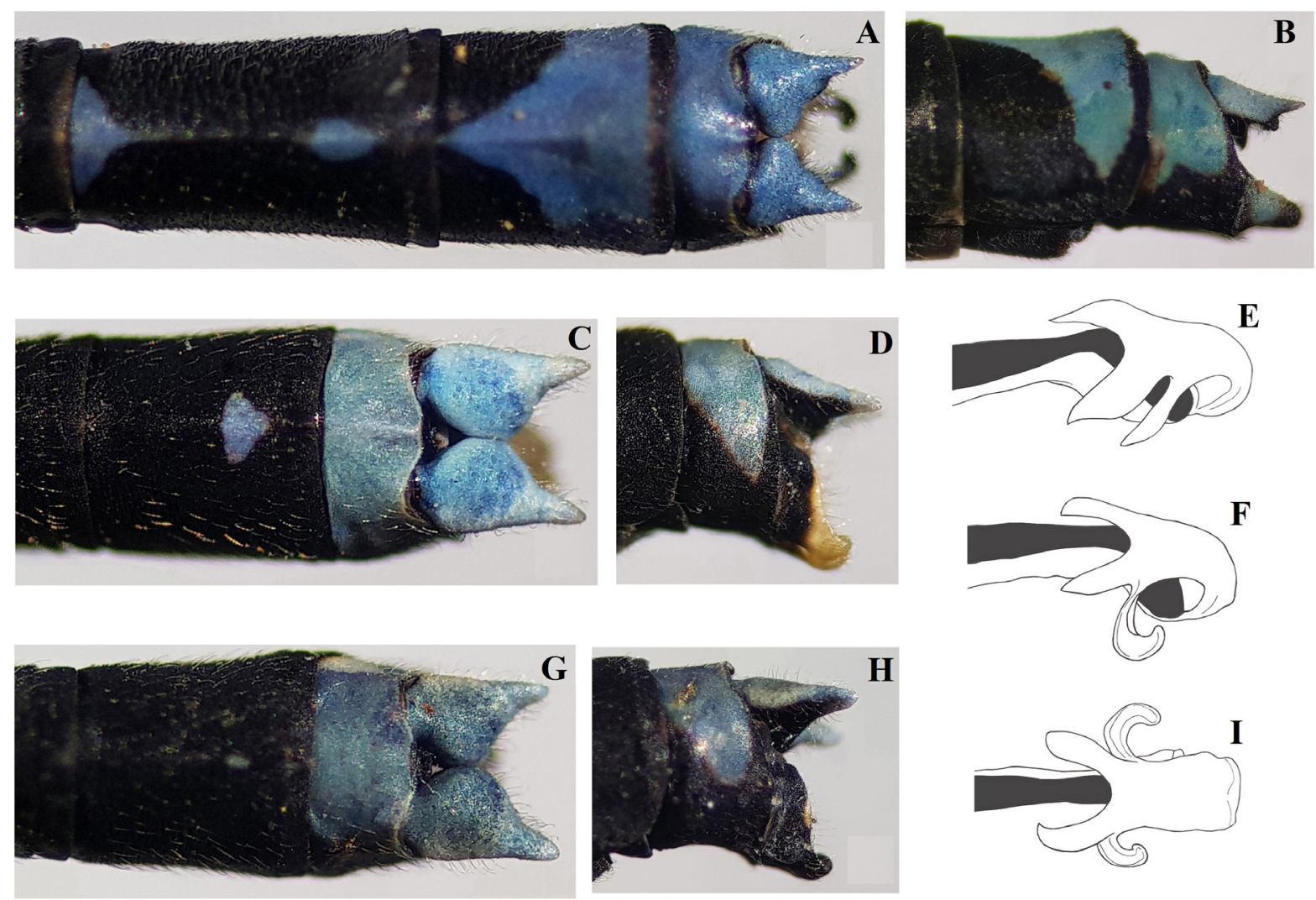

Fig. 3. Prodasineura Cowley, 1934 spp., males. A-B, E. P. coerulescens (Fraser, 1932), ZCDTU 2016100801-ODO. C-D, F. P. doisuthepensis Hoess, 2007, ZCDTU 2017062201-ODO. G-I. P. hoffmanni Kosterin, 2015, ZCDTU 2017062202-ODO. A, C, G = tip of abdomen, dorsal view; $\mathrm{B}, \mathrm{D}, \mathrm{H}=$ tip of abdomen, lateral view. E-F, I: Genital ligula, oblique-ventral view. Images not to scale. 
Province • 1 \} \text { ; Chu Yang Sin National Park; } 1 8 \text { May 2018; Q.T. Phan leg.; ZCDTU 2018051802-ODO. } - Dak Nong Province - 3 ổ; Nam Nung Nature Reserve; 25 Nov. 2019; Q.T. Phan leg.; ZCDTU 2019112502-ODO.

\section{Diagnosis}

Male resembling $P$. coerulescens with blue markings on head, thorax, abdomen, appendages. Male easily distinguished from $P$. coerulescens by markings of abdomen tip: small blue dot on S9 and S10 blue on dorsum (Fig. 3G-H) while S8-10 largely blue in P. coerulescens (Fig. 3A-B). Female very similar to male in body colouration, including green tones ventrally; antehumeral stripes narrow (Fig. F). Structure, shape of female posterior pronotal lobe of prothorax similar in these species but lobes converging, enclosing roundish space, in P. hoffmanni (Fig. 5F), not converging, enclosing semicircular space, in P. doisuthepensis (Fig. 5C).
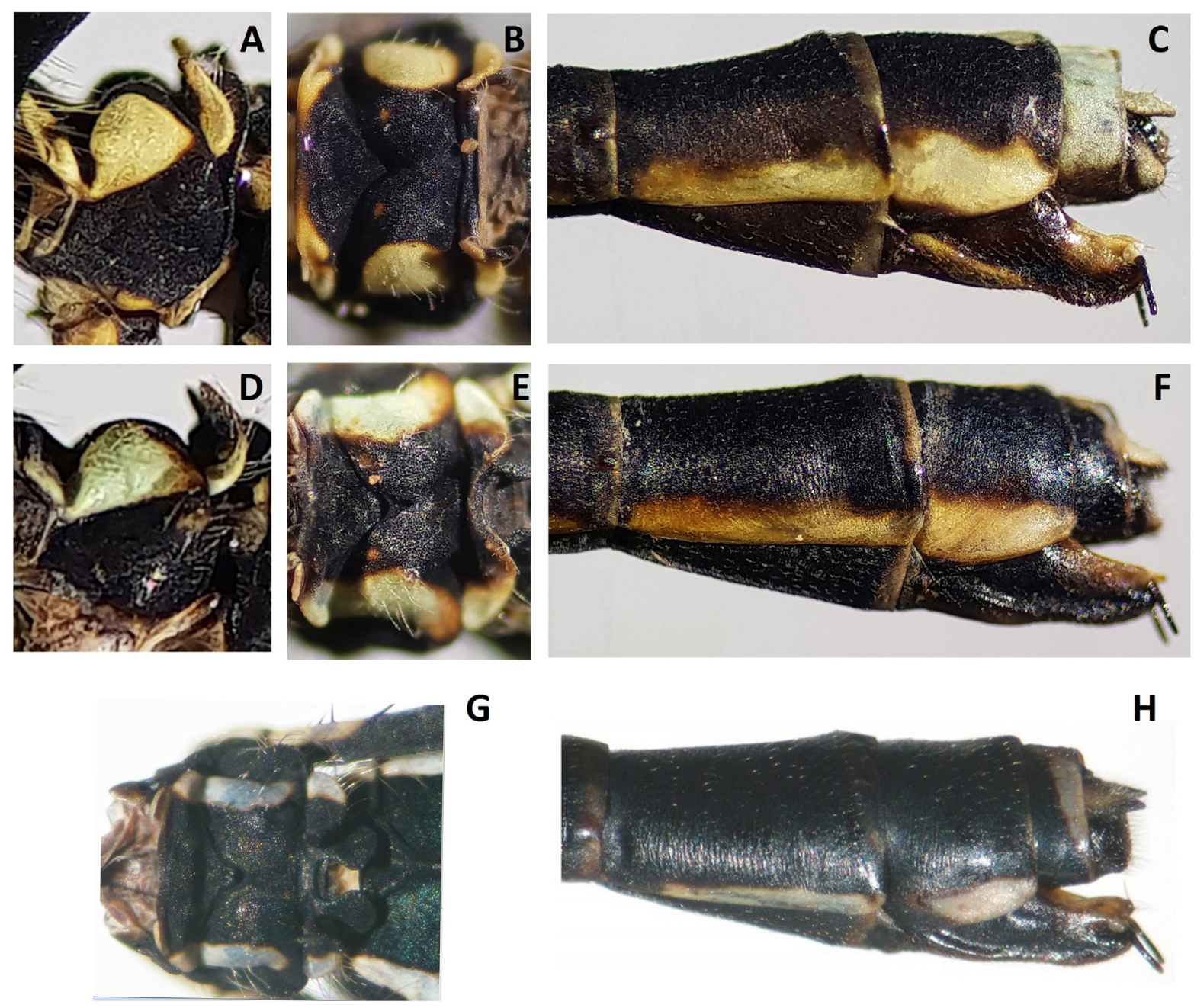

G

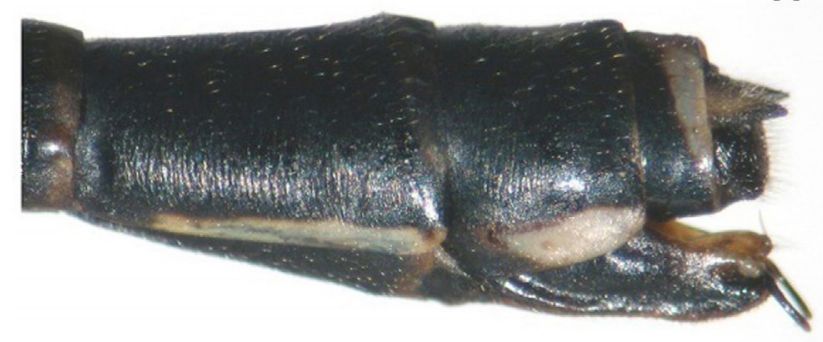

Fig. 4. Prodasineura Cowley, 1934 spp., females. A-C. P. coerulescens (Fraser, 1932), ZCDTU 2016100801-ODO. D-F. P. doisuthepensis Hoess, 2007, ZCDTU 2017062201-ODO. G-H. P. hoffmanni Kosterin, 2015, ZCDTU 2017062202-ODO. A, D = prothorax, lateral view; B, E, G = prothorax, dorsal view; C, F, H = tip of abdomen, lateral view (Fig. 4G-H is modified from in Kosterin 2015: fig. 4c, h). Images not to scale. 


\section{Remarks}

This species was described from Mondulkiri Province in Cambodia close to the border of Vietnam (Kosterin 2015) and has been recorded from Lam Dong and Dong Nai Provinces of South Vietnam (Kosterin 2016). Yokoi \& Souphanthong (2014) provided colourful photos of two bluish Prodasineura

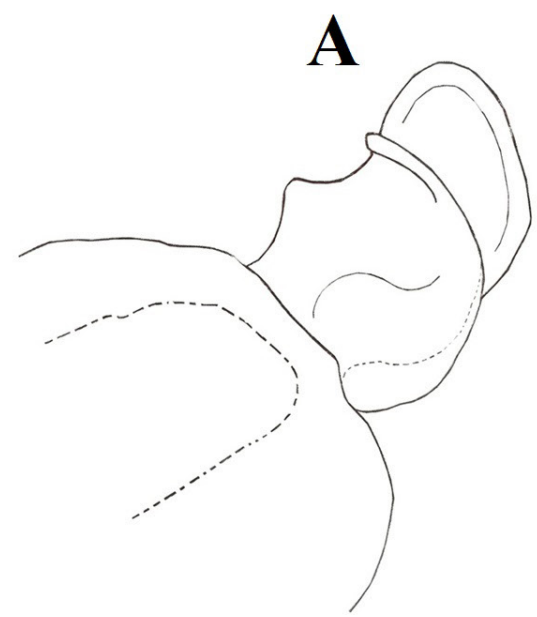

autumnalis

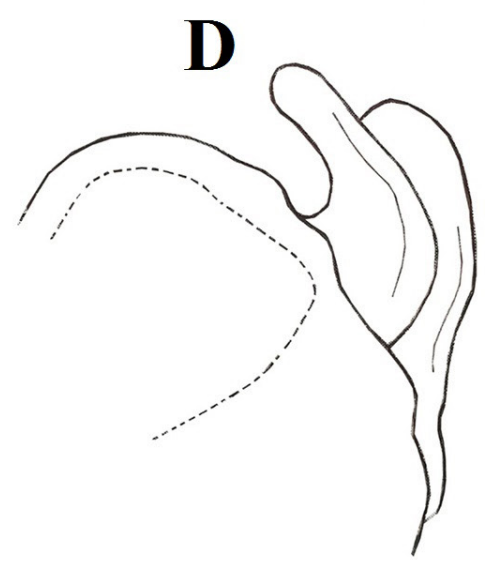

coerulescens
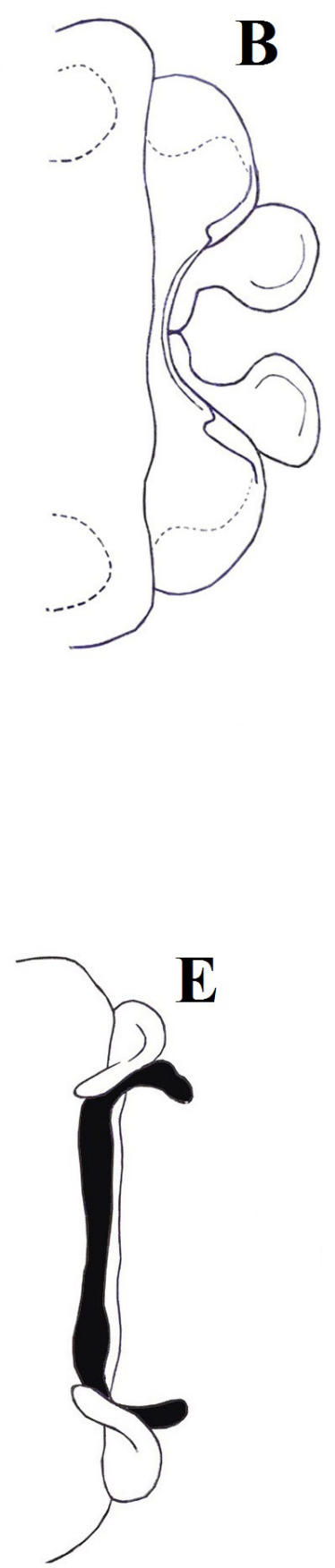

doisuthepensis
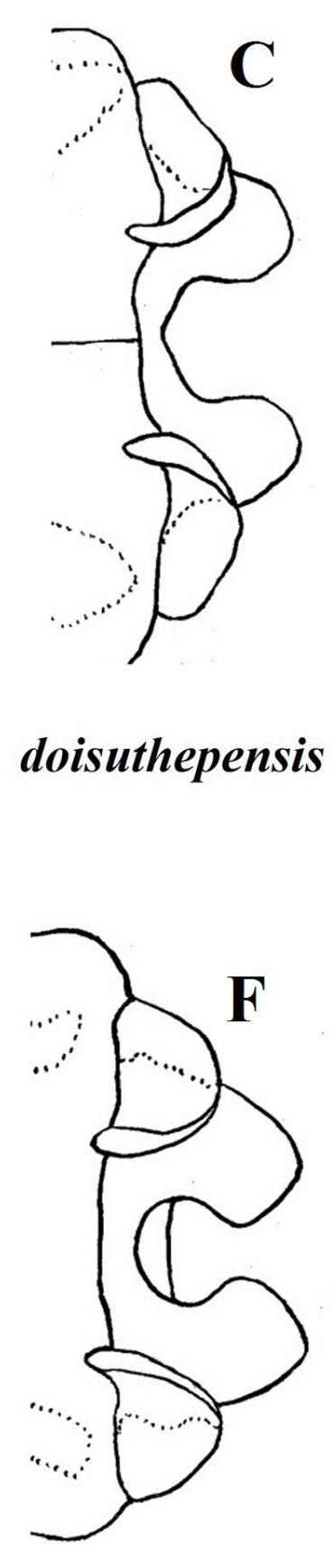

hoffmanni

Fig. 5. Posterior pronotal lobe of prothorax of Prodasineura Cowley, 1934 spp., females. A-B. P. autumnalis (Fraser, 1922), lateral and dorsal views. C. P. doisuthepensis Hoess, 2007, dorsal view. D-E. P. coerulescens (Fraser, 1932), lateral and dorsal views. F. P. hoffmanni Kosterin, 2015, dorsal view. (Fig. 5C, F is modified from Kosterin 2015: fig. 3c-d). Images not to scale. 
species in Laos that resemble P. hoffmanni (Prodasineura sp. 1 and sp. 2 in Yokoi \& Souphanthong 2014: 34). Therefore, it is likely that $P$. hoffmanni occurs in Laos as well.

\section{Distribution}

Vietnam (Fig. 17): Kon Tum (Kon Plong District), Dak Lak (Chu Yang Sin National Park), Dak Nong (Nam Nung Nature Reserve), Lam Dong (Bao Loc District and Da Lat) and Dong Nai (Cat Tien National Park) Provinces (Kompier 2019; Kosterin 2016; this study).

Prodasineura croconota Ris, 1916

Figs 6A-C, 7A-C, 8A-C, 13A-B, 16B, 18

\section{Material examined}

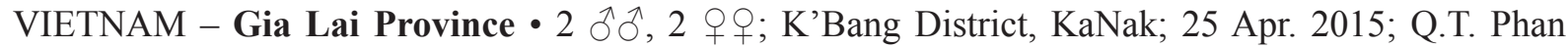
leg.; ZCDTU 2015042502-ODO. - Ha Tinh Province • 3 ô ô, 2 우; Vu Quang National Park; 7 Sep. 2015; Q.T. Phan leg.; ZCDTU 2015090702-ODO. - Quang Nam Province • 1 đ; Cu Lao Cham Island, 25 Sep. 2015; Q.T. Phan leg.; ZCDTU 2015092502-ODO • 1 ऽ̊; Tay Giang District, Bhalee Commune;

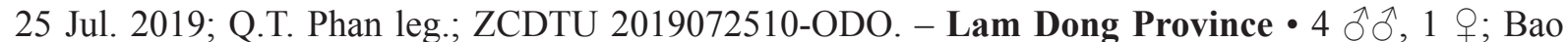
Loc District, Bao Lam; 11 Mar. 2016, Q.T. Phan leg.; ZCDTU 2016031101-ODO • 1 đ; Bao Loc District, Dambri; 12 Jul. 2017; Nguyen Dang Van leg.; ZCDTU 2017071702-ODO. - Quang Binh

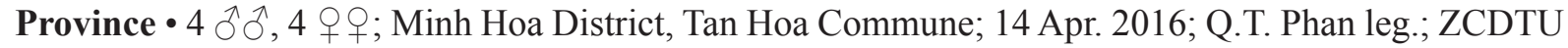
2016041401-ODO. - Da Nang City • 1 đ; Hai Van, Van village; 21 Feb. 2017; Q.T. Phan leg.; ZCDTU

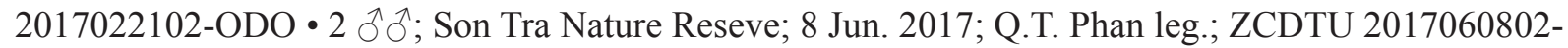
ODO. - Khanh Hoa Province 4 ठ $\precsim$; Hon Ba Nature Reserve; 28 Mar. 2018; Q.T. Phan leg.; ZCDTU

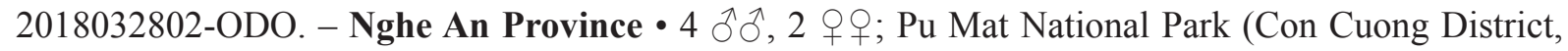
Mon Son Commune); 13 May 2019; Q.T. Phan leg.; ZCDTU 2019051302-ODO.

\section{Diagnosis}

Male characterized by large egg-shaped orange-yellow markings on dorsum of synthorax (Fig. 6A, C); head dorsally with two small spots adjacent to ocellar tubercle (Fig. 6A); cerci varying from bluish to yellow dorsally, most of paraproct yellowish (Fig. 7A-B). Female differing from male by having transverse yellow stripe across epicranium, whitish stripes on synthorax, thin antehumeral stripes (Fig. 6B). Structure of posterior pronotal lobe of prothorax in dorsal view similar to that of P. autumnalis with two rounded processes posteriorly, two short, robust horns distally (Figs 8A-B, 13A-B).

\section{Distribution}

Vietnam (Fig. 18): Lang Son (Huu Lien Nature Reserve), Phu Tho (Xuan Son National Park), Thai Nguyen, Vinh Phuc (Me Linh), Nghe An (Pu Mat National Park), Ha Tinh (Huong Son District and Vu Quang National Park), Quang Binh (Minh Hoa District), Quang Tri, Quang Nam (Tay Giang District and $\mathrm{Cu}$ Lao Cham Islands), Da Nang (Son Tra Nature Reserve), Gia Lai (K'Bang District), Lam Dong (Bao Loc District) and Khanh Hoa (Hon Ba Nature Reserve) Provinces (Kompier 2019; T. Kompier pers. comm.; Phan \& Dinh 2016; Phan \& Ngo 2019; this study).

Prodasineura verticalis Selys, 1860

Figs 6D-F, 7D-F, 8D-E, 13G-H, 16A, 18

\section{Material examined}

VIETNAM - Kien Giang Province • 1 đ̇; Phu Quoc Island; 1 Jan. 2016; T. Kompier leg.; TKC・1 O’; Phu Quoc Island; 18 Apr. 2016; Q.T. Phan leg.; ZCDTU 2016041810-ODO • 3 §ैô, 1 o; Phu Quoc 
Island, Nui Chua; 6 Mar. 2018; To Van Quang leg.; ZCDTU 2018030611-ODO. - Lam Dong Province

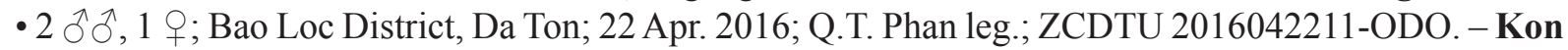

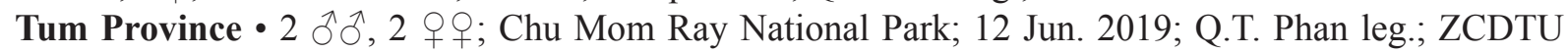
2019061211-ODO.

\section{Diagnosis}

In Vietnam, males of both $P$. croconota and $P$. verticalis with large egg-shaped orange markings on dorsum of synthorax but those in $P$. croconota shorter and broader than in P. verticalis (Fig. 6C-D), less saturated in colouration. In males of $P$. croconota, head with two small spots dorsally adjacent to ocellar tubercle (Fig. 6A) but with large transverse stripe in P. verticalis (Fig. 6E). Cerci in P. verticalis
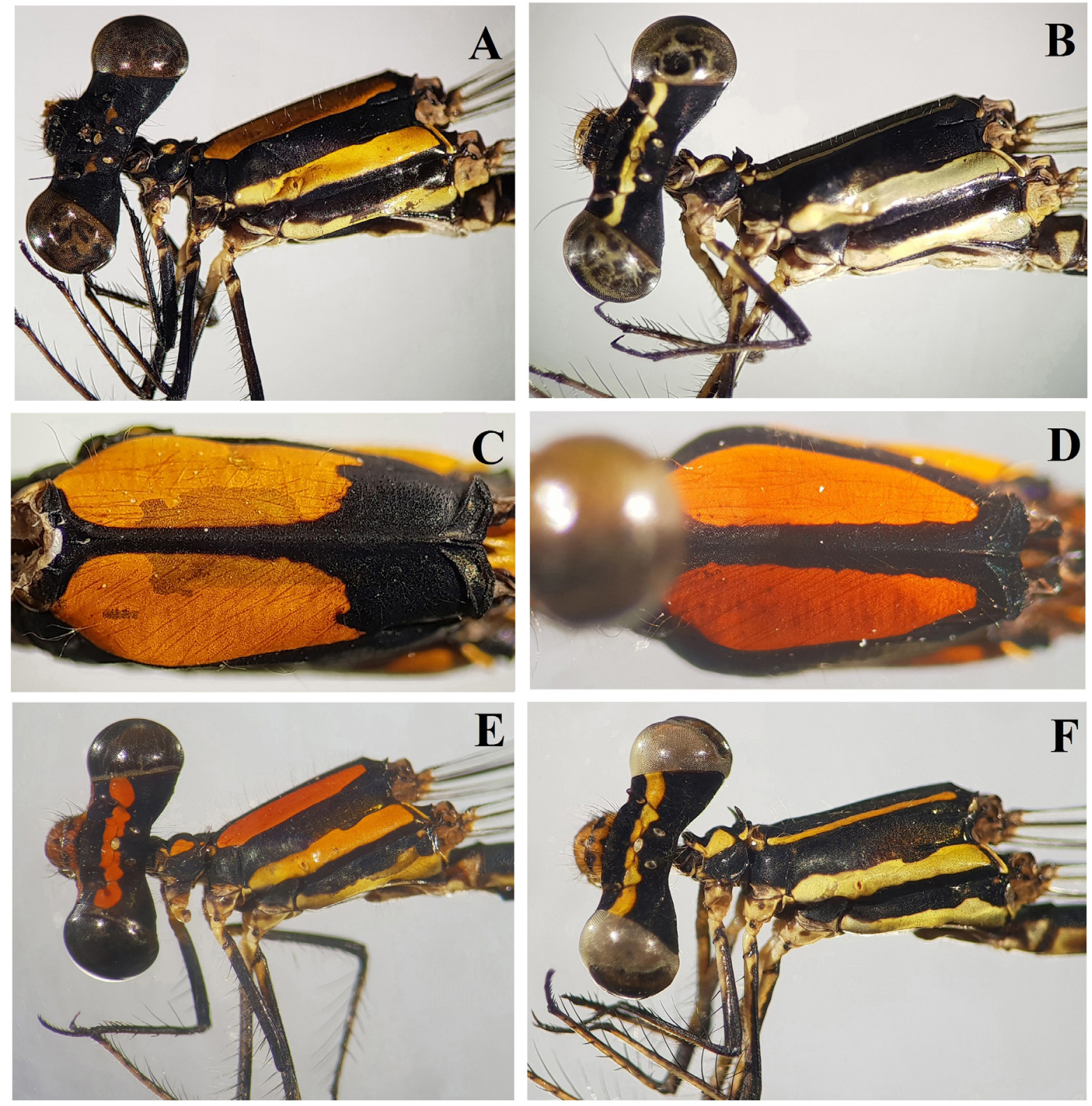

Fig. 6. Prodasineura Cowley, 1934 spp. A-C. P. croconota Ris, 1916, ZCDTU 2017060802-ODO. D-F. P. verticalis Selys, 1860, ZCDTU 2018030611-ODO. A, E = Oे, head and thorax, lateral view; $\mathrm{C}-\mathrm{D}=\hat{\mathrm{O}}$, synthorax, dorsal view; $\mathrm{B}, \mathrm{F}=\uparrow$, head and thorax, lateral view. Images not to scale. 
mostly black except for indistinct basal yellow stripe dorsally (Fig. 7D-E) while cerci dorsally entirely yellowish or bluish in $P$. croconota (Fig. 7A-B); ultimate segment of genital ligula of $P$. verticalis acute at apex (Fig. 7F) but blunt in P. croconota (Fig. 7C). Posterior pronotal lobe of prothorax of female $P$. verticalis characterized by two thin, long horns (Fig. 13G-H) while robust and short in $P$. croconota (Fig. 13A-B).

\section{Remarks}

Bui (2007) recorded Elattoneura sp. at Phu Quoc Island, which subsequently was reidentified as a Prodasineura sp. by Do et al. (2011). Based on examination of specimens, it was identified as P. verticalis by Kompier (2019). This paper confirms the identification of the Prodasineura species from Phu Quoc Island recorded in Bui (2007), Do et al. (2011) and Kompier (2019) was P. verticalis. Asahina (1997) presumed that a male from Mai Chau of Hoa Binh Province (northern Vietnam) was probably P. verticalis (see in Asahina 1997: 20, figs 7-8). However, according to Asahina, this was "a pale bluish striped, black-bodied species", which is not consistent with $P$. verticalis with orange stripes. Asahina's drawing shows a species with thin antehumeral stripe, which may well be Prodasineura coerulescens, which occurs also in the similar lowland limestone forest in Quang Binh Province, rather than P. hoffmanni (see in Asahina 1997: 20, figs 7-8) which is recorded further south from primary forest of the Central Highlands or evergreen forests in Cat Tien National Park. Asahina's (1997) male should be re-examined to establish its identity with certainty.

\section{Distribution}

Vietnam (Fig. 18): Kon Tum (Chu Mom Ray National Park), Lam Dong (Bao Loc District), Dong Nai (Cat Tien National Park) and Kien Giang (Phu Quoc Island) Provinces (Kompier 2019; this study).
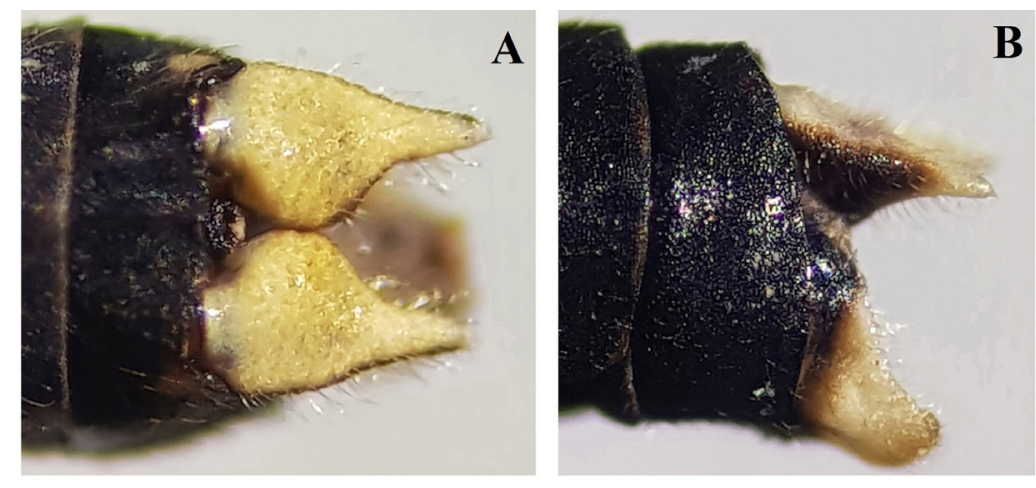

B
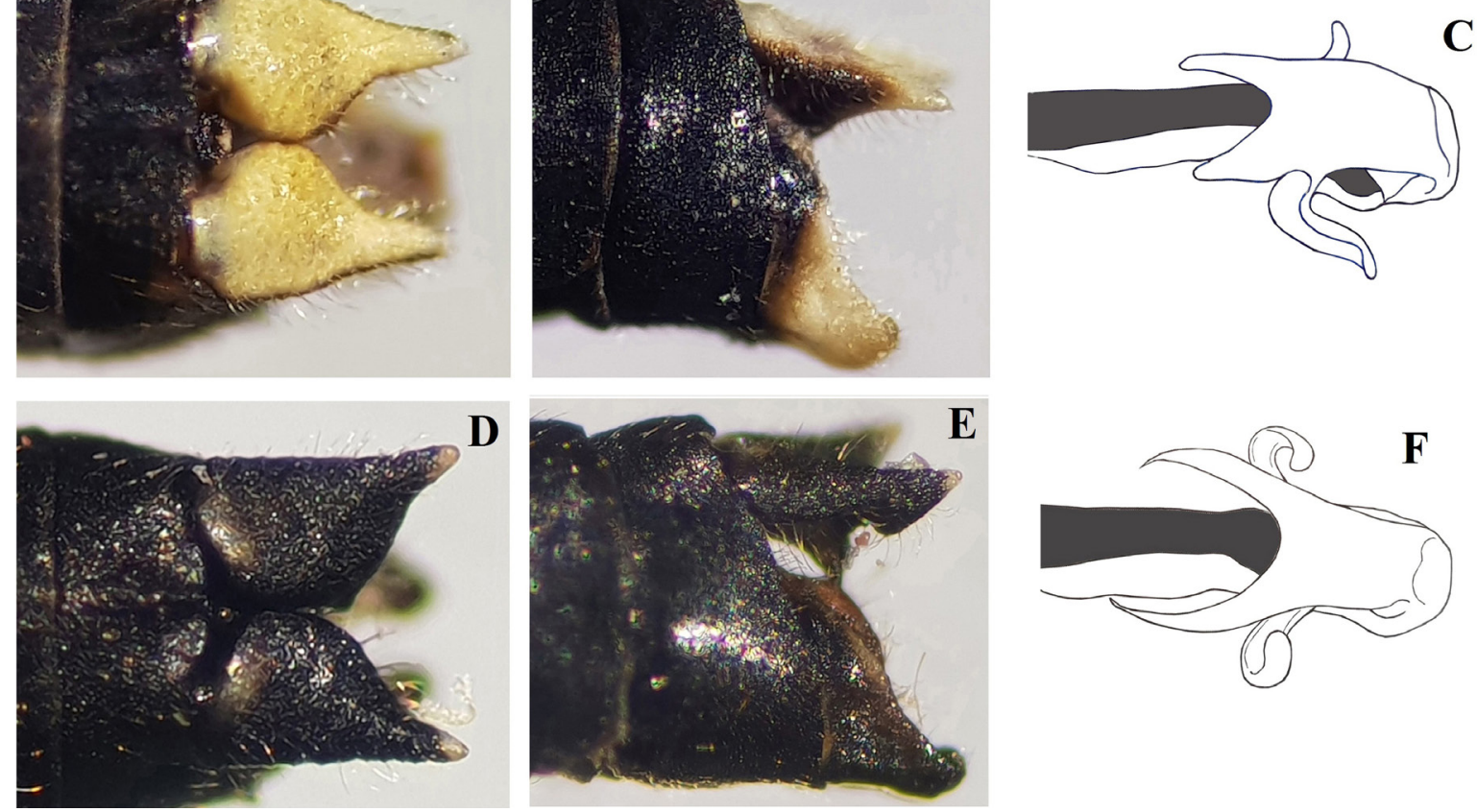

Fig. 7. Prodasineura Cowley, 1934 spp., males. A-C. P. croconota, ZCDTU 2017060802-ODO. D-F. P. verticalis Selys, 1860, ZCDTU 2018030611-ODO. A, D, G = tip of abdomen, dorsal view; $\mathrm{B}, \mathrm{E}=$ tip of abdomen, lateral view; $\mathrm{C}, \mathrm{F}=$ genital ligula, oblique-ventral view. Images not to scale. 
Prodasineura laidlawi (Forster in Laidlaw, 1907) - excluded species

Fig. 8F

\section{Diagnosis}

Bluish Prodasineura that resembles $P$. coerulescens and $P$. hoffmanni with thin antehumeral stripe, bluish abdominal tip, appendages in males. Bluish marking covers most of S9, extends to $\mathrm{S} 8$ in $P$. laidlawi while only dorsal area of S9 blue in P. coerulescens and P. hoffmanni (Kosterin 2015). Female easily separated from $P$. coerulescens and $P$. hoffmanni by posterior pronotal lobe of prothorax having large rounded plate mid-centrally (Fig. $8 \mathrm{~F}$ ) rather than two separate ear-like processes, disposed laterally in P. coerulescens (Fig. 5D), midposteriorly in P. hoffmanni (Fig. 5F).

\section{Remarks}

Asahina (1969) reported P. laidlawi from Dinh Quan District of Dong Nai Province, but included no figures of its structures. Other studies in Cat Tien National Park and Dinh Quan District of Dong Nai Province record the similarily marked species $P$. coerulescens but not $P$. laidlawi (Do \& Dang 2007; Kompier 2019; this study). We suggest that the male of $P$. laidlawi as identified by Asahina (1969) was probably $P$. coerulescens. The occurence of $P$. laidlawi in Vietnam is also unlikely given the known range of P. laidlawi, which has been reported from Malaysia (Orr 2005) and Thailand (Asahina 1983).
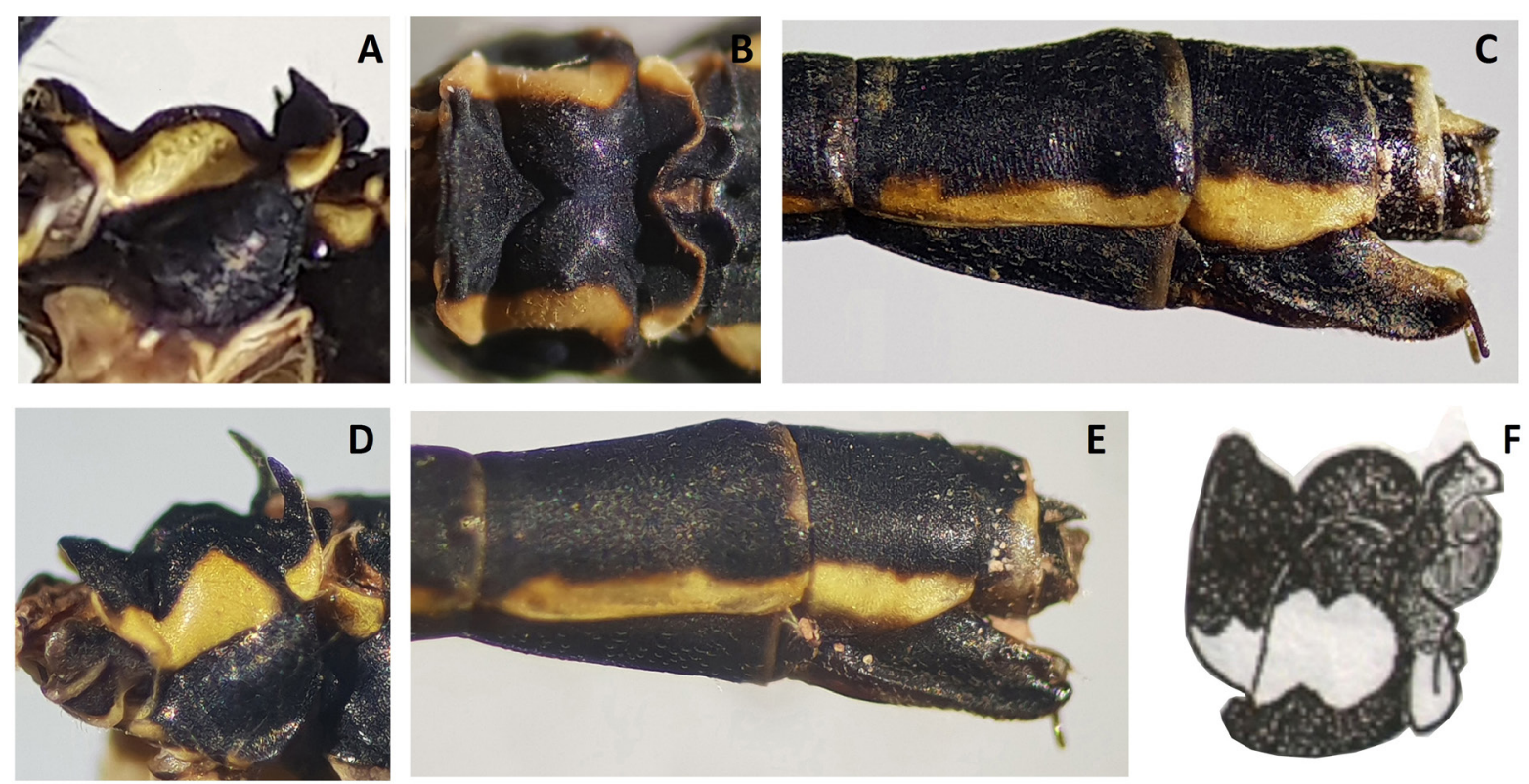

Fig. 8. Prodasineura Cowley, 1934 spp., females. A-C. P. croconota Ris, 1916, ZCDTU $2017060802-$ ODO. D-E. P. verticalis Selys, 1860, ZCDTU 2018030611-ODO. F. P. laidlawi (Forster in Laidlaw, 1907), modified from Asahina (1983: fig. 22). A, G-F = prothorax, lateral view; $B, D=$ prothorax, dorsal view; $\mathrm{C}, \mathrm{E}=$ tip of abdomen, lateral view. Images not to scale. 
Prodasineura kong sp. nov.

urn:1sid:zoobank.org:act:6BEEA763-7AFB-4426-B919-024387DEC48E

Figs 9A, C-D, 10A-B, 11A, C, E, 12A-B, 13C-D, 14A-B, 15A, 16C, 18

\section{Diagnosis}

Male very similar to those of $P$. croconota and $P$. verticalis but differing in following characters: large transversal stripe on dorsal surface of head (Fig. 9A), interrupted centrally, not connecting, covering anterior ocellus as in P. verticalis (Fig. 6E) (with small spots in P. croconota, Fig. 6A); antehumeral stripe narrow (Fig. 9A), not large shield-shaped as in P. croconota and P. verticalis (Fig. 6C-D). In fully mature specimens, paraprocts of $P$. verticalis entirely black (Fig. 7D-E) while yellow apically in $P$. kong sp. nov. (Fig. 9C). Cerci distinctly different in shape (Fig. 9C, E). Cerci, paraprocts yellow or bluish (except for black ventral side of cerci and base of paraprocts) in P. croconota (Fig. 7A-B). Structure of posterior pronotal lobe of female prothorax somewhat similar to that in P. croconota (Fig. 13A, D) with two short, robust horns, unlike two long horns of P. verticalis (Fig. 13G-H). Prodasineura kong sp. nov. similar to $P$. lancastrei $\mathrm{sp}$. nov. by sharing same character of narrow antehumeral stripe on male synthorax, but males differ very much in structure of appendages, wing colouration. Females differ in structure of posterior pronotal lobe (see Diagnosis for P. lancastrei sp. nov.).

\section{Etymology}

The new species is named after the giant ape Kong since it was discovered at the filming location of the American monster film "Kong: Skull Island", in Tu Lan Caves System of Quang Binh Province, central Vietnam. A noun in apposition.
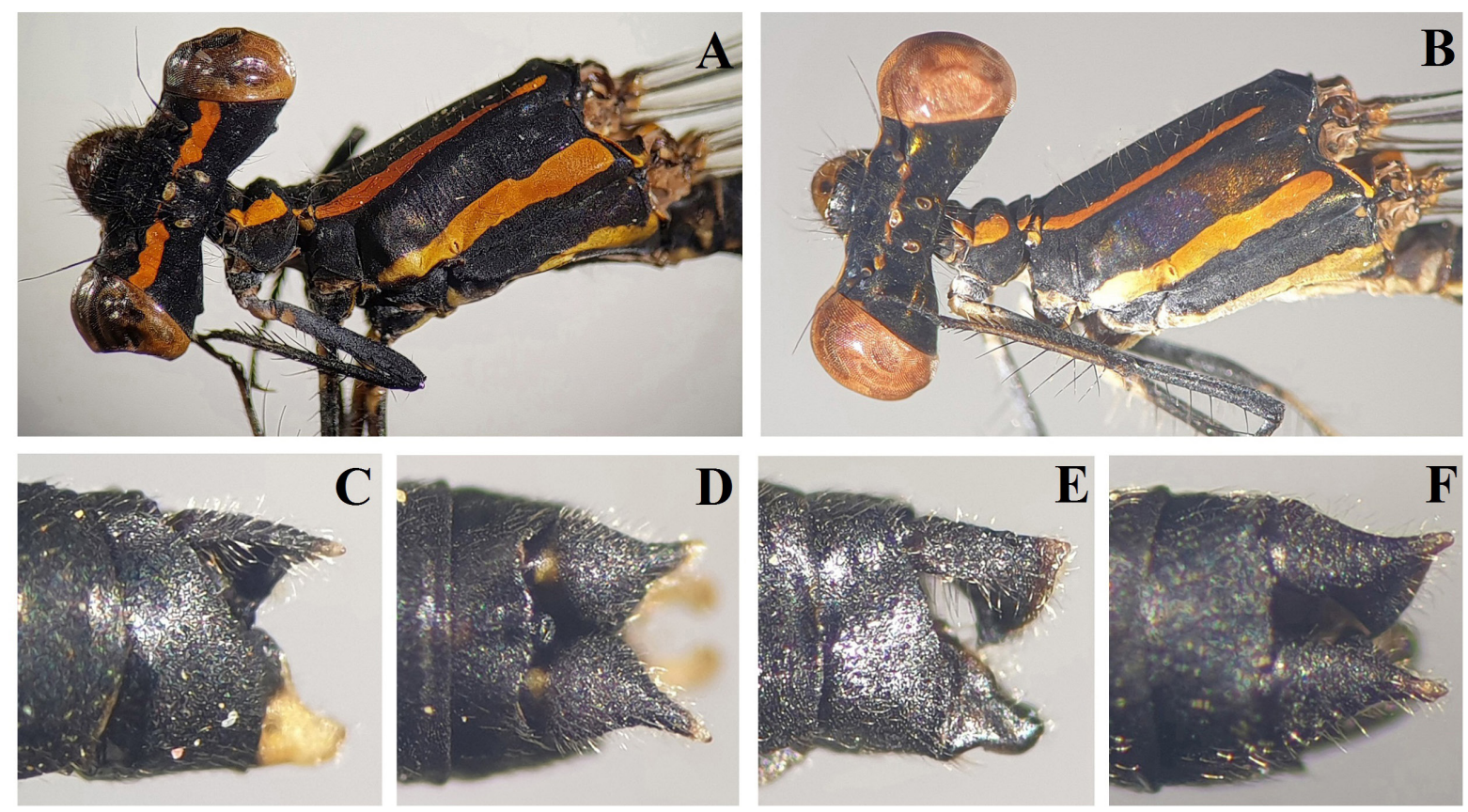

Fig. 9. Structures of Prodasineura Cowley, 1934 spp., males, holotypes. A, C-D. P. kong sp. nov., ZCDTU 2019071811-ODO. B, E-F. P. lancastrei sp. nov., ZCDTU 2019051212-ODO. A-B = head and thorax, lateral view; $\mathrm{C}, \mathrm{E}=$ appendages, lateral view; $\mathrm{D}, \mathrm{F}=$ appendages, dorsal view. Images not to scale. 


\section{Material examined}

Holotype

VIETNAM • O; $^{\wedge}$ Quang Binh Province, Minh Hoa District, Tan Hoa Commune; $17.776^{\circ} \mathrm{N}, 106.0701^{\circ} \mathrm{E}$; 144 m a.s.1.; 18 Jul. 2019; Q.T. Phan \& Q.P. Ngo leg.; ZCDTU 2019071811-ODO.

Paratypes $(9$ $ぇ, 2$ 우)

VIETNAM - Quang Binh Province - 1 t ; same collection data as for holotype; 14 Apr. 2016; Q.T. Phan leg.; ZCDTU 2016041412-ODO • 5 채, 2 우우; same collection data as for holotype; ZCDTU

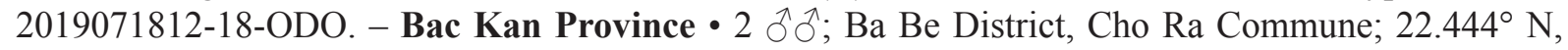
$105.846^{\circ}$ E; 25 Jun. 2014; T. Kompier leg.; RMNH. - Cao Bang Province • 1 đo; Cao Bang City; $22.681^{\circ} \mathrm{N}, 106.273^{\circ} \mathrm{E} ; 20$ May 2015; T. Kompier leg.; RMNH.

\section{Description}

Male (Figs 9A-C, 10A-B, 12A, 14A, 15A)

MEASUREMENTS. Hind wing $20 \mathrm{~mm}$, abdomen (including appendages) $31 \mathrm{~mm}$.

HEAD. Labrum, mandible, genae, anteclypeus dark red except for upper genae; upper genae black. Space between eye margins, genae shining black (Fig. 9A). Frontal, dorsal surfaces of head, including postclypeus, antennae, matt black except for large orange transverse stripe running from eye margins across anterior ocellus (Fig. 12A).

THORAX. Prothorax black with orange markings on distal margin of each pronotal lobe as follows: thin stripe on anterior lobe, small spots on posterior lobe, large oval spot on middle pronotal lobe (Fig. 9A). Propleuron entirely black. Synthorax black with narrow orange antehumeral stripe; two other distinct stripes: paler orange on metepisternum, yellowish on lower margin of metepimeron (Fig. 9A).

LEGS. Mostly black except for some small dark yellow spots on coxa, trochanter, femur; flexor surface of tibia dark yellowish.
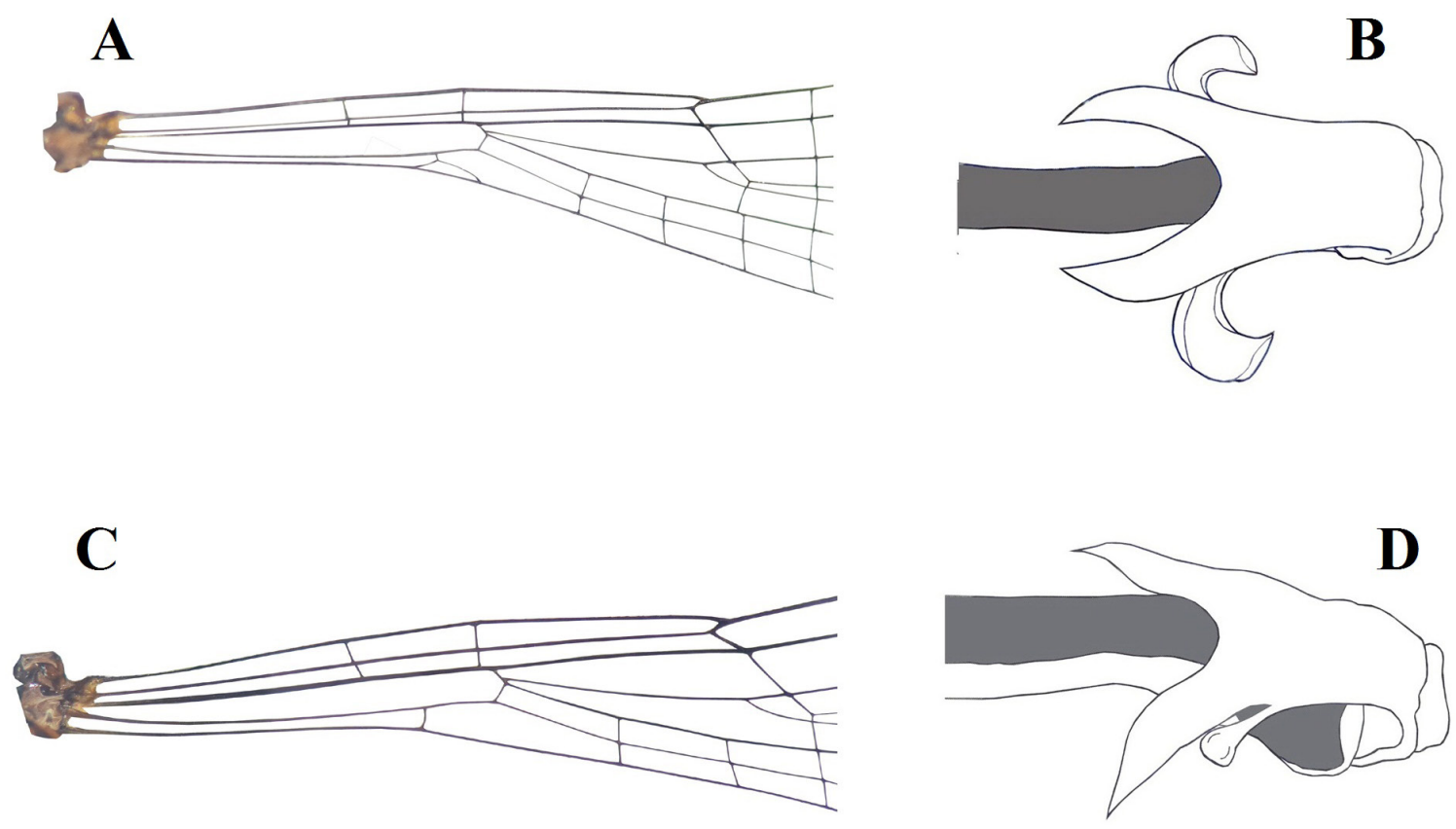

Fig. 10. Wings base and genital ligula of Prodasineura Cowley, 1934 spp., males, holotypes A-B. P. kong sp. nov., ZCDTU 2019071811-ODO. C-D. P. lancastrei sp. nov., ZCDTU 2019051212-ODO. Images not to scale. 
Wings. Completely hyaline, Px 16, 14 in forewings, hindwings respectively. Pterostigma black (Fig. 10A).

AвDOMEN. Mostly black except: yellow triangular spots on lower margins of S1; yellowish bands on ventro-lateral surfaces of S2; small spot on anterior margin of S3, whitish spot on dorsal anterior margin of S4-7; S8-10 entirely black (Fig. 14A).

AnAl APPENDAgEs. Typical of members of genus Prodasineura with cerci hammer-like shaped; paraprocts broad at base, tapering abruptly to rounded tip; cerci black excepted tip dark yellowish; paraprocts black at base; remain yellowish (Fig. 9C-D).

Genital Ligula. Latero-apically with two robust flagella with pointed tips; subbasal shorter flagellum, expanding apically as rounded lobe (Fig. 10B).

Female (Figs 11A, C, E, 12B, 13C-D, 14B)

MEASUREMENTS. Hindwing $20.5 \mathrm{~mm}$, abdomen (including appendages) $31 \mathrm{~mm}$.

HEAD Figs 11A, 12B. Labrum yellowish with black dot beneath upper margin; mandibles, genae yellowish except for small black dot near anteclypeus; yellow colour extends from compound eyes just
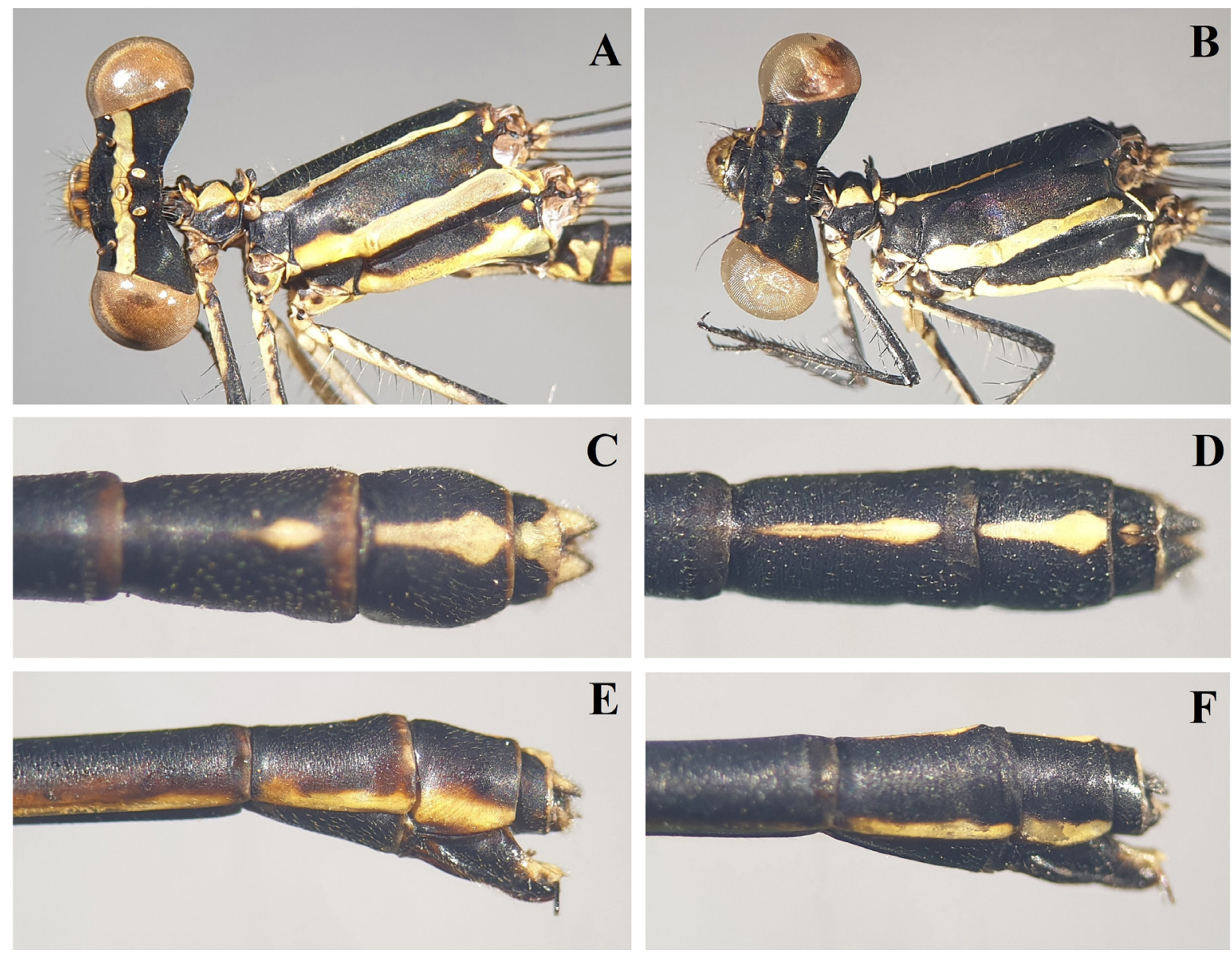

Fig. 11. Prodasineura Cowley, 1934 spp., female paratypes. A, C, E. P. kong sp. nov., ZCDTU 2019071817-ODO. B, D, F. P. lancastrei sp. nov., ZCDTU 2019051217-ODO. A-B = head and thorax, lateral view; $\mathrm{C}-\mathrm{D}=$ abdominal tip, dorsal view; $\mathrm{E}-\mathrm{F}=$ abdominal tip, lateral view. Images not to scale. 
over postclypeus to level of base of antennae; antennae black; anteclypeus dark yellowish; postclypeus yellow with two separated black spots, black stripe centrally. Antennae black except for second segment, yellowish anteriorly. Front, rear of head black with large transverse yellowish stripe at level of anterior ocellus.

Thorax Figs 11A, 13C-D. Prothorax black, laterally yellowish, forming large oval stripe on middle pronotal lobe. In dorso-oblique view, posterior lobe with pair of raised robust anterior projections, two ear-like processes (Fig. 13C-D). In dorsal view, projections sharply curving upward (Fig. 13D). Synthorax black with three yellow stripes (Fig. 11A).

LEGS. Coxae yellowish with large outer black spot; trochanter yellow with flexor side black; tibia, tarsus, claws black.

Wings Fig. 14B. Hyaline, forewings slightly longer than hindwings, Px 15, 13 in forewings, hindwings respectively. Pterostigma brown.

AвDOMEN Figs 11C, E, 14B. Black with yellowish pattern: S1 with heart-shaped spot on lateral sides; S2 with narrow yellowish stripes along lower margins; ventro-lateral halves of S3-6 brown-yellowish with oval yellowish spot on anterior margin of each segments; S7 dark brownish and S8-9 black with yellowish stripe on lower margin; dorsal side of S8 with oval yellow spot posteriorly but extending to mid-dorsally on S9; lower margin of S10 black but with yellowish marking dorsally (Fig. 11C).

ApPENDAGES. Yellowish except for lower margin of cerci; cerci dark brownish; ovipositor black, distal end yellowish (Fig. 11C, E).

\section{Variation in male and female paratypes}

Paratypes from Bac Kan with some orange on dorsum of cerci; male from type location with incomplete transverse band between compound eyes over anterior ocellus. Male from Cao Bang with small orange
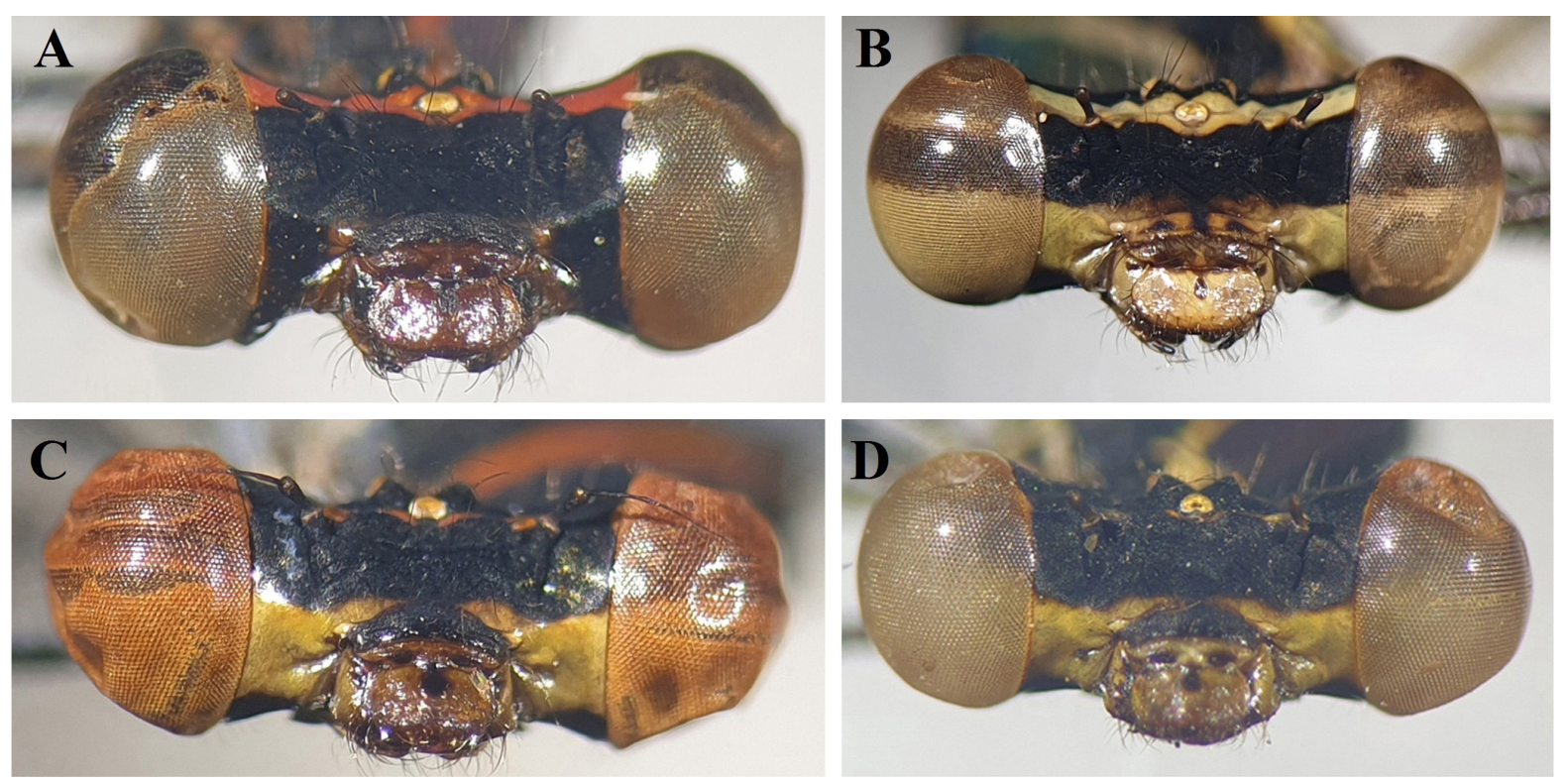

Fig. 12. Head of Prodasineura Cowley, 1934 spp., frontal view. A-B. P. kong sp. nov. A. đ, holotype, ZCDTU 2019071811-ODO. B. +, paratype, ZCDTU 2019071817-ODO. C-D. P. lancastrei sp. nov. C. holotype, ZCDTU 2019051212-ODO. D. + , paratype, ZCDTU 2019051217-ODO. Images not to scale. 
spot on posterodorsal corner of propleuron. Other male paratypes from type location provided no significant differential features from holotype male. Compound eyes bright red in living male (Fig. 15A). Stripes on male synthorax bright orange in life (Fig. 15A), but stripe on lower margin of metepimeron becoming yellowish after acetone treatment in holotype (Fig. 9A).

Measurements. Hind wing 20-21 mm, abdomen (including appendages) 30-31 mm.

\section{Distribution}

Vietnam (Fig. 18): Cao Bang (Cao Bang City), Bac Kan (Ba Be District) and Quang Binh (Minh Hoa District) Provinces.

\section{Habitat and ecology}

The new species was collected in Quang Binh from an open stream (about 3-6 m wide) with fast running water a low limestone mountain area (Fig. 16B). This species usually flies over the surface of water, fighting with two other species of Prodasineura present, for occupation of the habitat near the border of the stream, the blue $P$. coerulescens and the dark P. autumnalis.

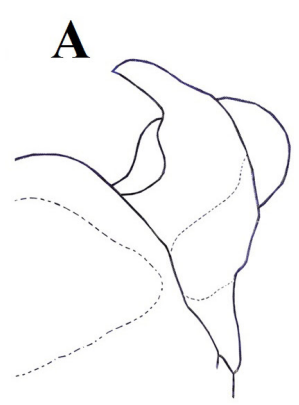

croconota

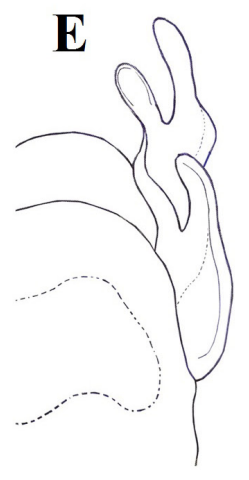

lancastrei
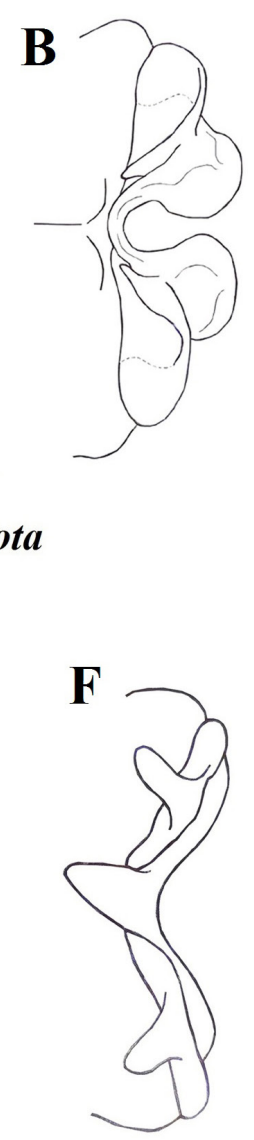

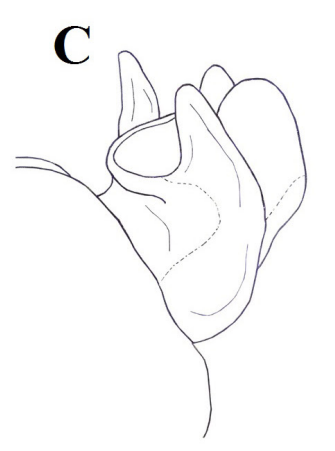

kong
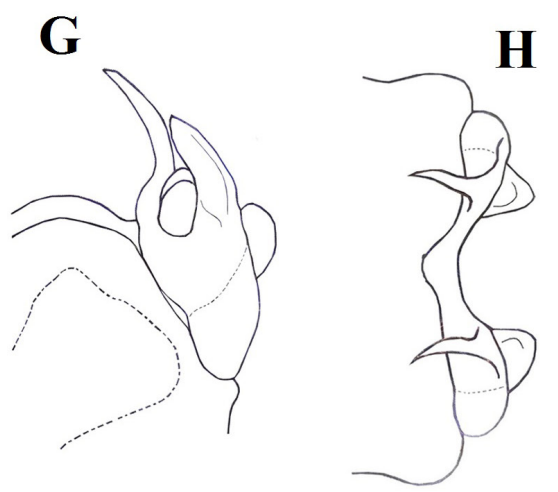

verticalis

Fig. 13. Posterior pronotal lobe of prothorax of Prodasineura Cowley, 1934 spp., females, lateral and dorsal views. A-B. P. croconota Ris, 1916, ZCDTU 2017060802-ODO. C-D. P. kong sp. nov., ZCDTU 019071817-ODO. E-F. P. lancastrei sp. nov., ZCDTU 2019051217-ODO. G-H. P. verticalis Selys, 1860, ZCDTU 2018030611-ODO. Images not to scale. 
Prodasineura lancastrei sp. nov.

urn:1sid:zoobank.org:act:6A004DD2-86D3-455A-A266-B7139FA6AFF0

Figs 9B, E-F, 10C-D, 11B, D, F, 12C-D, 13E-F, 14C-D, 15B, 16B, 18

\section{Diagnosis}

Differing from most other congeners and all Vietnamese species of Prodasineura by darkened apical wings (Fig. 14C) in male and morphology of posterior pronotal lobe with three flattened horns in female (Fig. 13E-F). In Vietnam, $P$. lancastrei is superficially most similar to $P$. kong by sharing the same thin antehumeral stripe on the male synthorax (Fig. 9A-B), but differing by the following characters: in male, transverse band on dorsal head of $P$. lancastrei narrow (Fig. 9B), wider in P. kong (Fig. 9A); appendages of $P$. lancastrei mostly black (Fig. 9E-F), paraprocts yellowish apically in $P$. kong (Fig. 9C-D); cerci of $P$. lancastrei (Fig. 9E) in lateral view not pointed, ventral expansion convex along posterior margin as opposed to concave in P. kong (Fig. 9C). Female of P. lancastrei differing by three horns (Fig. 13E-F) in stead of two short, robust horns in P. kong (Fig. 13C-D).

\section{Etymology}

This species is named after Mr. Luis de Lancastre (born on 20 December 1990) in appreciation of his financial aid for our fieldwork. A noun in the genitive case.

\section{Material examined}

Holotype

VIETNAM - 3 ; Nghe An Province, Con Cuong District, Mon Son Commune, a small stream near Khe O Forestry Latch, Pha Lai Ranger Station; $19.52167^{\circ}$ N, $105.545^{\circ}$ E; 66 m a.s.1.; 12 May 2019; Q.T. Phan leg.; ZCDTU 2019051212-ODO

A
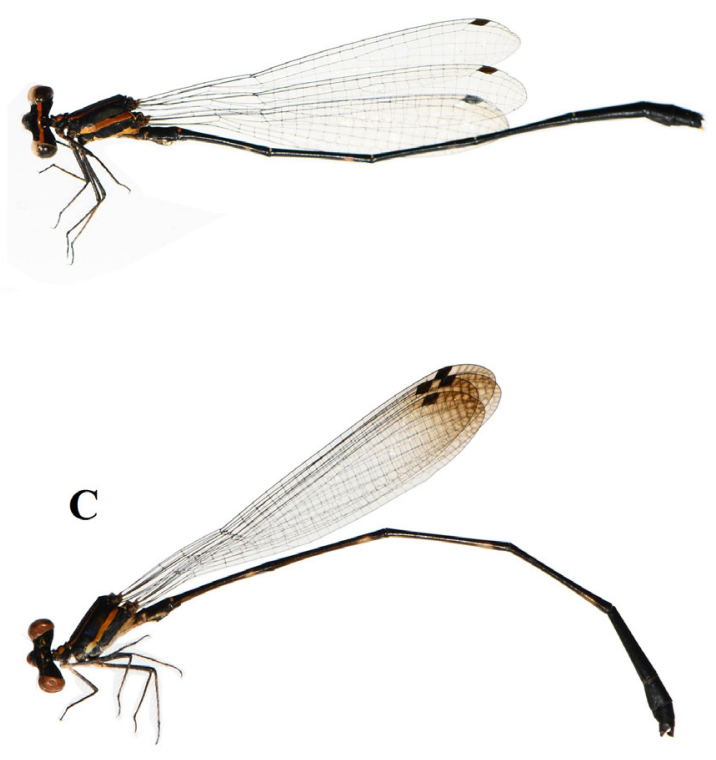

B
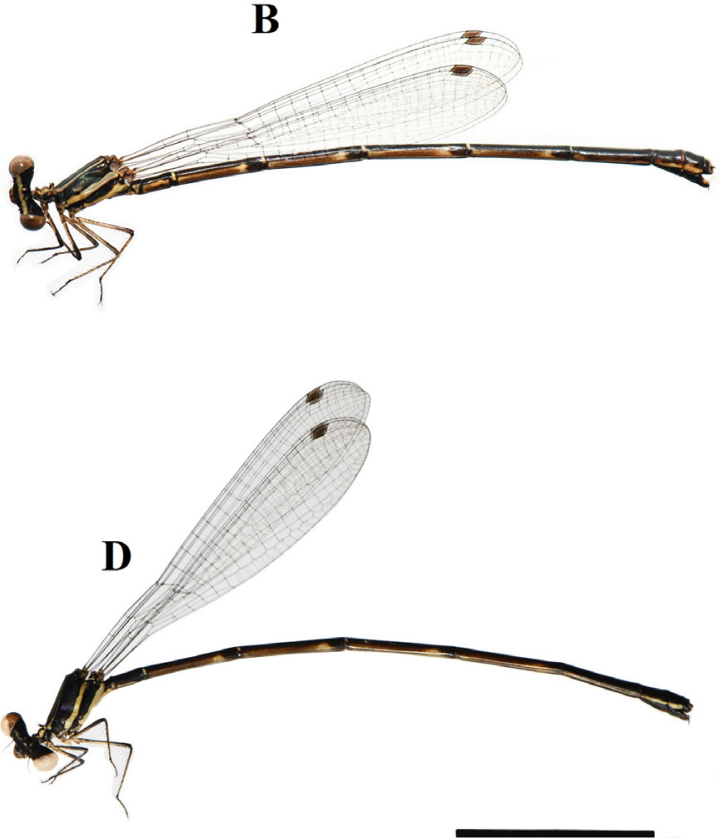

Fig. 14. Habitus of Prodasineura Cowley, 1934 spp. A-B. P. kong sp. nov. A. Ô, holotype, ZCDTU 2019071811-ODO. B. + , paratype, ZCDTU 2019071817-ODO. C-D. P. lancastrei sp. nov., C. Ô, holotype, ZCDTU 2019051212-ODO. D. + , paratype, ZCDTU 2019051217-ODO. Scale bar $=$ $1 \mathrm{~cm}$. 

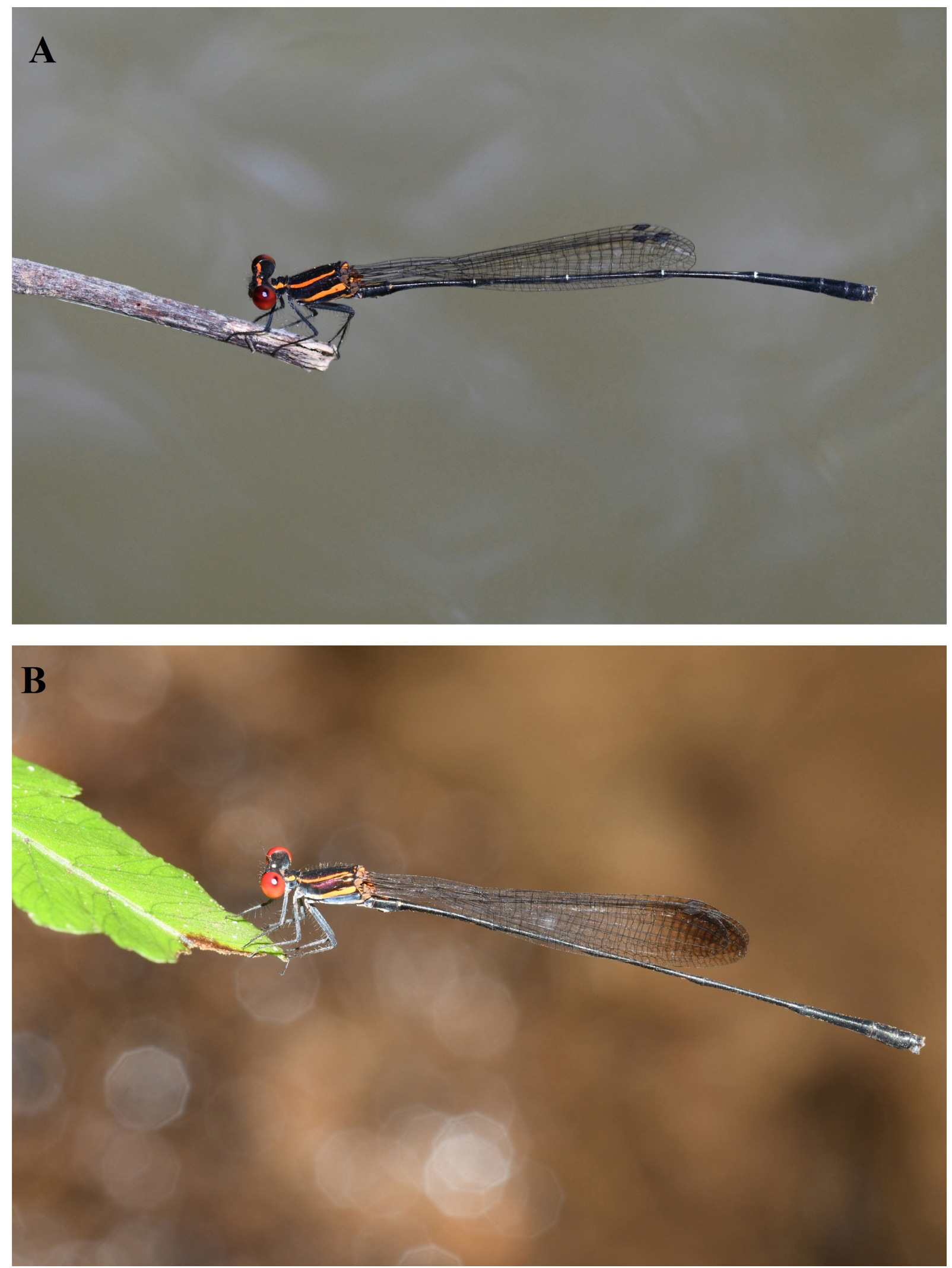

Fig. 15. Prodasineura Cowley, 1934 spp., males, in nature. A. P. kong sp. nov. B. P. lancastrei sp. nov. 

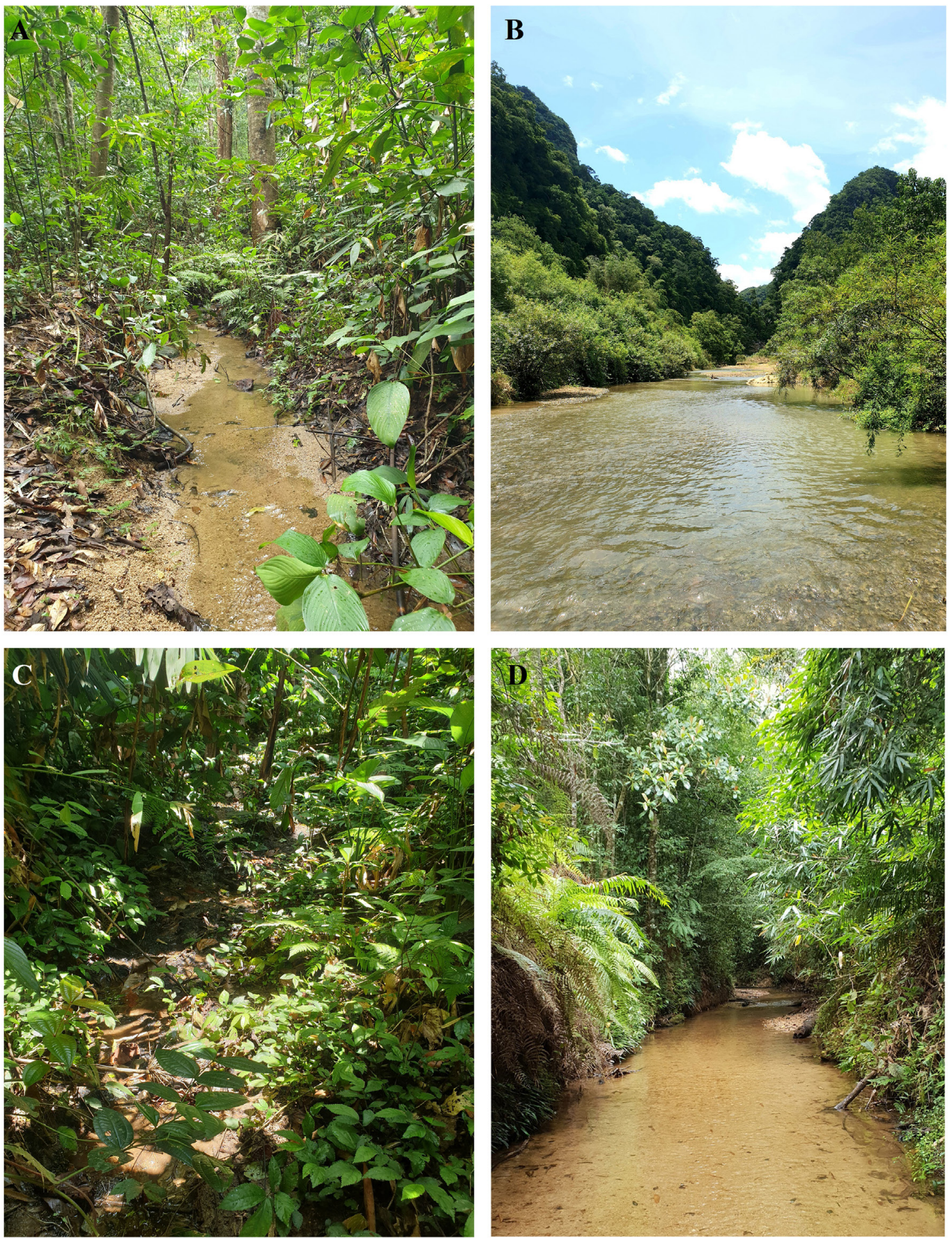

Fig. 16. Habitat of Prodasineura Cowley, 1934 spp. in Vietnam. A. Gia Trang stream in Chu Mom Ray National Park, home of $P$. doisuthepensis Hoess, 2007 and $P$. verticalis Selys, 1860. B. Typical stream where $P$. lancastrei sp. nov., $P$. autumnalis (Fraser, 1922) and $P$. croconota Ris, 1916 occur, in $\mathrm{Pu}$ Mat National Park. C. Open limestone stream in Tan Hoa Commune, Minh Hoa District of Quang Binh Province with three species: P. autumnalis, P. kong sp. nov. and P. coerulescens (Fraser, 1932) coexisting. D. Habitat of $P$. hoffmanni Kosterin, 2015 and P. autumnalis in Mang Canh, Kon Plong District of Kon Tum Province. 


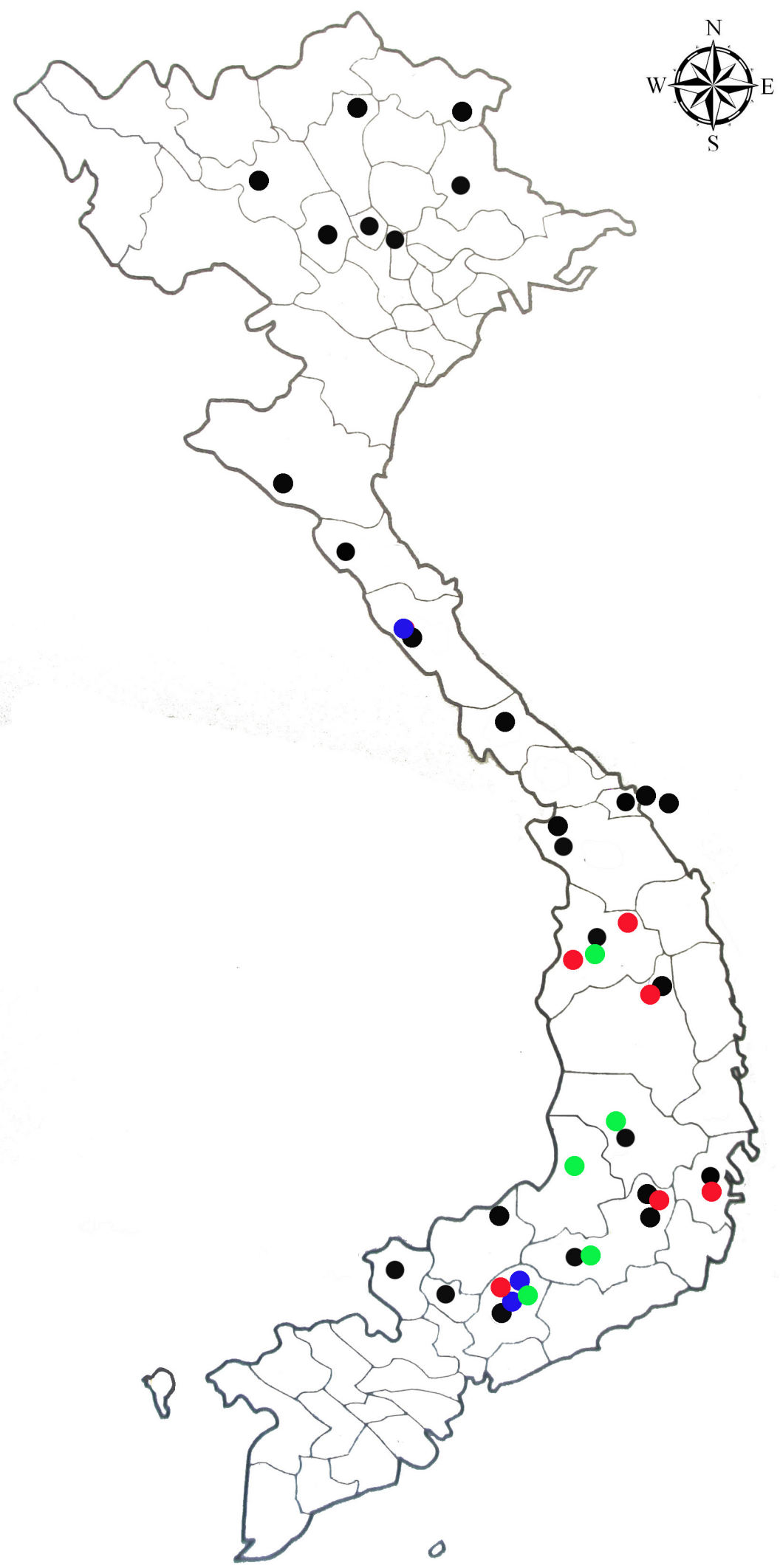

Fig. 17. Distribution map of Prodasineura Cowley, 1934 spp. in Vietnam (blue group species including the blackish $P$. autumnalis (Fraser, 1922)). $(\bullet)$ P. autumnalis. $(\bullet)$ P. coerulescens (Fraser, 1932). $(\bullet)$ P. doisuthepensis Hoess, 2007. (•) P. hoffmanni Kosterin, 2015. 


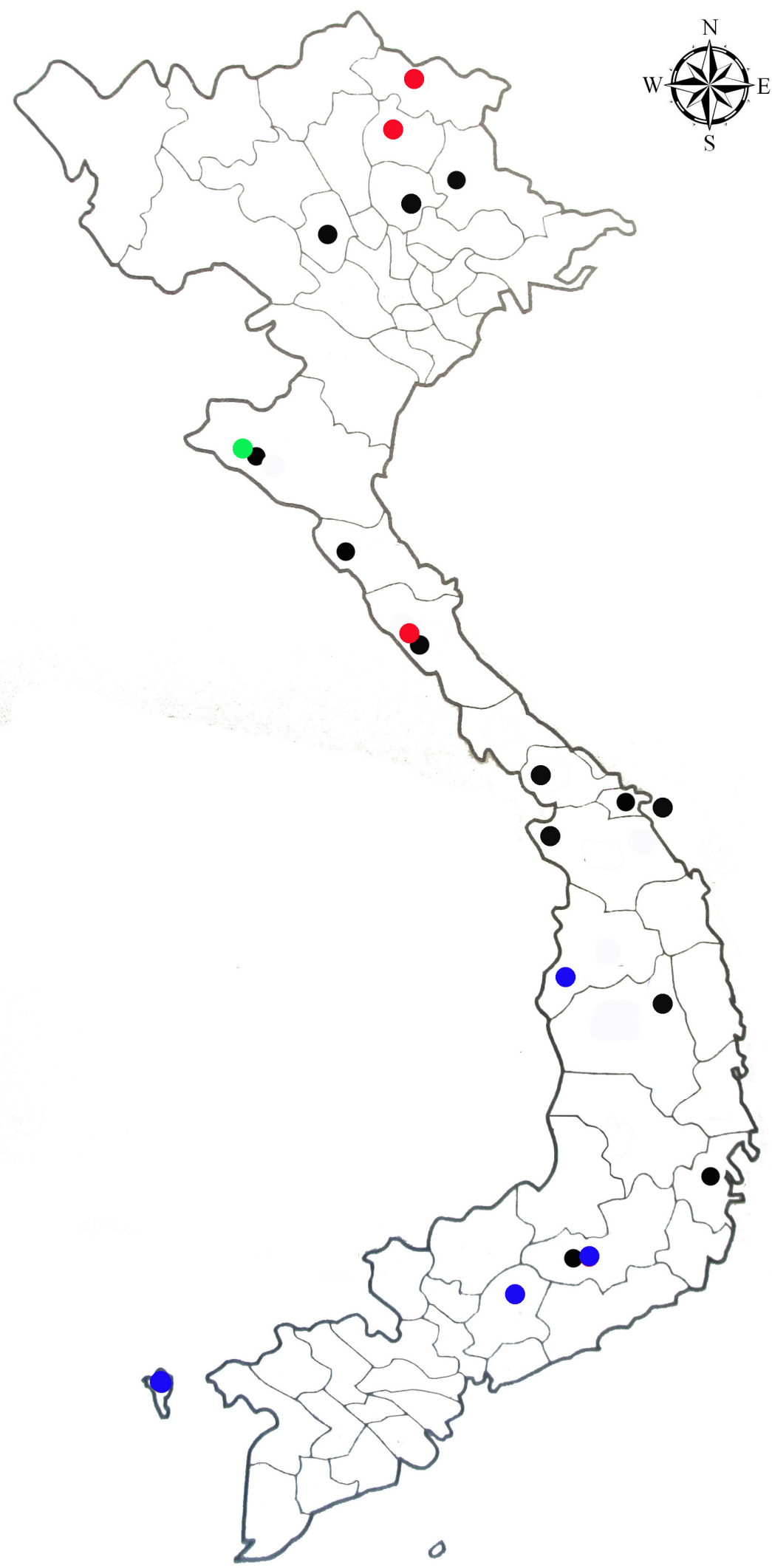

Fig. 18. Distribution map of Prodasineura Cowley, 1934 spp. in Vietnam (orange group species). (•) P. croconota Ris, 1916. (•) P. verticalis Selys, 1860. (•) Prodasineura kong sp. nov. (•) P. lancastrei sp. nov. 


\section{Paratypes}

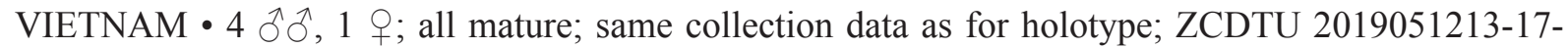
ODO.

\section{Description}

Male (Figs 9B, E-F, 10C-D, 12C, 14C, 15B)

MEASUREMENTS. Hindwing $19 \mathrm{~mm}$, abdomen (including appendages) $31.5 \mathrm{~mm}$.

HEAD. Labrum dark red with black dot medially. Mandibles yellow, pattern extending to level of postclypeus. Anteclypeus dark red, postclypeus matt black (Fig. 9B). Antennae entirely black. Front matt black except for complete narrow transversal reddish stripe running from eye margins, encompassing anterior ocellus. Rear of head entirely black (Fig. 12C).

THORAX. Prothorax black, orange markings as in Fig. 9B; distal margin of anterior, posterior pronotal lobe with small spot, middle of pronotal lobe with large oval spot. Propleuron entirely black. Synthorax black, on each side with narrow orange antehumeral stripe, two other distinct stripes: reddish one on metepisternum and yellowish ones on lower margin of metepimeron (Fig. 12C).

Legs. Coxae black, lateral yellow lines; trochanter yellow, flexor margin black; femur entirely black; tibia black, flexor surface yellow; tarsus, claws entirely black.

Wings. Hyaline, darkened from about level of pterostigma (Figs 10C, 14C, 15B). Forewings slightly longer than hindwings, Px 17, 14 in forewings, hindwings respectively. No anal bridge (Fig. 10C). Pterostigma black, covering slightly more than one underlying cell.

ABDOMEN. Mostly black except for yellow triangular spots at lower margins of S1; ventro-lateral sides of S2 with yellowish bands; S3-6 with dorsally interrupted half-rings along anterior margin; anterior S3 with orange spot; S7-10 entirely black (Fig. 14C).

Anal APPendages. Mostly black except for dark yellowish tips of cerci; cerci axe-shaped, broadened ventro-apically, paraprocts entirely black, broad at base, narrower toward blunt tip (Fig. 9E-F).

Genital Ligula. Typically shaped for Prodasineura species, two robust flagella lateroapically, extending posteriorly, pointed at tip, bearing subbasal shorter flagellum, which expands apically as rounded lobe (Fig. 10D).

Female (Figs 11B, D, F, 12D, 13E-F, 14D)

MEAsurements. Hindwing $18.5 \mathrm{~mm}$, abdomen (including appendages) $30 \mathrm{~mm}$.

HeAD. Labrum, mandibles, genea, anteclypeus yellowish except for black spot beneath lateral side of mandibles, border of genae black, two separated black spots on anteclypeus; this pattern over postclypeus at level of base of antennae (Fig. 11B). Postclypeus, antennae entirely black. Front, rear of head black, obscure tiny transverse yellowish stripe at level of anterior ocellus (Fig. 12D).

Thorax. Prothorax black, yellowish laterally (Fig. 11B). Posterior pronotal lobe with three flattened horns (Fig. 13F), strongly erect in lateral view (Fig. 13E). Antehumeral stripe yellow, not reddish as in male, shorter, interrupted at about $2 / 3$ of mesepisternum (Fig. 11B).

LEGS. Same as male. 
WINGs. Hyaline, forewings slightly longer than hindwings, Px 13, 12 in forewings, hindwings respectively. Pterostigma black (Fig. 14D).

ABDOMEN. Black, following pattern: S1 with two oval yellowish spots; S2 with narrow yellowish stripe along lower margin; S3-6 with dark reddish stripe along lower margin, oval yellowish spot on anterior segments, larger spot at about $3 / 4$ of each segment length (Fig. 14D); S7-9 black with yellowish stripe on lower margin; S10 black with oval yellow spot dorsally (Fig. 11D, F).

ApPendages. Entirely black; ovipositor black with distal end yellowish (Fig. 11D, F).

\section{Variation in male paratypes}

Two paratype males having yellowish compound eyes due to acetone treatment for preservation, other features of paratype specimens showing no significant differential features from holotype male. Compound eyes bright red in living males (Fig. 15B).

\section{Distribution}

Vietnam (Fig. 18): Nghe An (Con Cuong District, Mon Son Commune) Province.

\section{Habitat and ecology}

The new species was found in a densely vegetated, very narrow (about $1 \mathrm{~m}$ width) branch (Fig. 16C) of a shaded, shallow, narrow (about 1-3 m width) and rocky forest mountain stream with slow running water and a sandy bottom. Two other species of Prodasineura (P. autumnalis and P. croconota) occurred in the same stream with $P$. lancastrei sp. nov.

\section{Key to the males and females of Prodasineura species from Vietnam}

Males of all Vietnamese species of Prodasineura can be separated into two main colourational groups (except for the sole black synthoracic species $P$. autumnalis) based on the colouration of the male thorax: the blue group (including $P$. coerulescens, $P$. hoffmanni and $P$. doisuthepensis) and the orange group (including $P$. croconota, $P$. verticalis, $P$. kong sp. nov. and $P$. lancastrei $\mathrm{sp}$. nov.).

\section{Males}

1. Synthorax with whitish stripes, becoming very dark or complete black in fully mature individuals (Fig. 1A) P. autumnalis (Fraser, 1922)

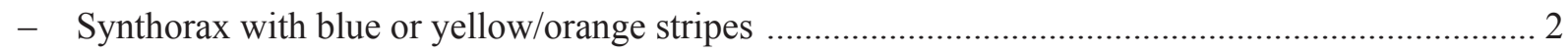

2. Synthorax and abdominal tip, sometimes including cerci with blue marking .................................. 3

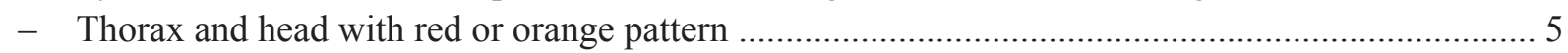

3. Synthorax with large blue oval markings on mesepisternum (Fig. 2C)

- Synthorax with a narrow antehumeral stripe ......

4. S8-10 largerly blue, paraproct with blue marking (Fig. 3A-B) .........P. coerulescens (Fraser, 1932)

- S9 with a small blue dot, S10 largely blue, paraproct entirely black (Fig. 3G-H)

5. Synthorax with large orange oval spots on mesepisternum 6

- Synthorax with narrow antehumeral stripe 
6. The large oval marking never extending to the end of the mesepisterum (Fig. 6C); dorsal side of head mostly black with two small orange spots (Fig. 6A); appendages mostly yellow or blue (Fig. 7AB)

P. croconota Ris, 1916

- The large oval marking covering most of mesepisternum (Fig. 6D); wide transverse band on dorsal head side (Fig. 6E); appendages mostly black (Fig. 7D-E) P. verticalis Selys, 1860

7. Wide transverse band on dorsal side of head (Fig. 9A); cerci posterior margin concave in lateral view; paraprocts yellowish apically (Fig. 9C-D)

P. kong sp. nov.

- Very narrow transverse band on dorsal side of head (Fig. 9B); cerci posterior margin concave in lateral view, axe-shaped; paraproct entirely black (Fig. 9E-F).

P. lancastrei sp. nov.

\section{Females}

We collected all studied species of Prodasineura in Vietnam in pair or tandem in order to exactly define the female of each species, except for the female of $P$. hoffmanni, which is still lacking in our collection. All characters of the female of $P$. hoffmanni used in this key are adopted from Kosterin (2015).

1. Posterior pronotal lobe with three flattened projections without a pair of ear-like structures (Fig 13EF)

P. lancastrei sp. nov.

- Posterior pronotal lobe with two horns and two adjacent ear-like structures 2

2. Posterior pronotal lobe possesses two long sharp horns, strongly upward curving (Fig. 13GH) P. verticalis Selys, 1860

- Posterior pronotal lobe with two short and robust horns 3

3. The horns well developed, smoothly curving anteriorly in lateral view

- The horns very short, slightly raising anteriorly in lateral view (Fig. 5A-B)

P. autumnalis (Fraser, 1922)

4 The pair of raised processes small, well separated (Fig. 5D-E)

P. coerulescens (Fraser, 1932)

- The pair of raised processes well developed, positioned more centrally

5 The robust horns curving upward, two ear-like structures well separated by a space greater than their own diameter (Fig. 13C-D)

P. kong sp. nov.

- The robust horns strongly curving anteriorly, two ear-like structure are set closer to each other, separated by a broad incision (Fig. 5C)

6 Dorsal side of head and thorax with yellowish pattern (Fig. 6B)

P. croconota Ris, 1916

- Dorsal side of head and thorax with blue pattern (Fig. 2E, G)

7 Anteclypeus black, two ear-like structures are set closer to each other and converging, separated by a roundish incision (Kosterin 2015) (Fig. 5F)

P. hoffmanni Kosterin, 2015

- Anteclypeus ochre-yellow with a black central stripe (Fig. 2E), two ear-like structures separated by a broad semicircular incision, not converging (Kosterin 2015) (Fig. 5C)

P. doisuthepensis Hoess, 2007

\section{Discussion}

The two genera Prodasineura and Elattoneura Cowley, 1935 are probably artificial and monophyletic since they were separated from each other by the degree of the anal bridge development (Cowley 1934, 1936). According to their current definition, ab nervure is always complete in the genus Elattoneura while in Prodasineura it is considered to be either incomplete or a short arch (as in Fig. 10A of P. kong) or absent (as in Fig. 10C of P. lancastrei). However, the axe-shaped cerci of P. lancastrei (Fig. 9E) are 
unique among species of Prodasineura but of the same shape as in the current species of Elattoneura and Disparoneura. The colouration, especially the entirely bright-red eyes, of $P$. lancastrei (Fig. 15B) comes closest to E. atkinsoni Selys, 1886 but the darkened wings of the male suggest some proximity to Disparoneura, especially D. apicalis (Fraser, 1924) (O. Kosterin pers. comm.). The relationships between the numerous Asian species currently attributed to these two genera Prodasineura and Elattoneura are poorly understood (Dijkstra et al. 2014; Kosterin 2015). Prodasineura lancastrei obviously appears to be more related to Elattoneura atkinsoni or Disparoneura apicalis than to any species of Prodasineura, irrespective of its generic attribution. However, in spite of the anal bride being unreliable for generic subdivision as an evolutionary flexible structure, we decided to describe this new species under the genus Prodasineura as formally fitting its current definition. It should also be noted that the central horns in the female prothorax of P. lancastrei (Fig. 13E-F) are unusually structured for all three genera Prodasineura, Elattoneura and Disparoneura which possess only paired structures and no central processes.

\section{Acknowledgements}

We are thankful to the following persons: Mr Tom Kompier and Dr Oleg Kosterin for extensive review of the manuscript and for additional records and material; Dr Oleg Kosterin and Dr Rosser Garrison for reviewing and revising the drafts of the manuscript; Dr Le Nguyen Bao, provost of the Duy Tan University, and Mr Luis de Lancastre for supporting the field trips; Dr Martin Schorr and Dr Akihiko Sasamoto for providing many relevant publications; Mr Nguyen Viet Hung (Vu Quang National Park), Mr Nguyen Anh Tuan (Pu Mat National Park) and Mr Hoang Anh Tuan (Chu Mom Ray National Park) for their arrangement of the necessary permits for survey in the respective National Parks; Mr Hoang Quang Duy (Tay Nguyen University), Mr To Van Quang (Southern Institute of Ecology, Vietnam Academy of Science and Technology) and Mr Nguyen Dang Van (resident in Bao Loc District of Lam Dong Province) for providing specimens; IDEAL WILD Foundation for supporting the Nikkor micro lens as well as Mr Pham Anh Tuan (Duy Tan University) and Mr To Van Quang for helpful co-work in the field. This study was supported (in part) by the Nagao Natural Environment Foundation, Japan and the International Dragonfly Fund, Germany. This research is mainly funded by the Vietnam National Foundation for Science and Technology Development (NAFOSTED) under grant number 106.052018.351 .

\section{References}

Asahina S. 1969. South Vietnam Odonata taken by Mr. Inoue. Japanese Journal Zoology 16: 1-18.

Asahina S. 1983. A list of the Odonata recorded from Thailand. Part II. Protoneuridae. Kontyu, Tokyo 51: 90-99.

Asahina S. 1997. Records of the Northern Vietnamese Odonata taken by the Expedition Members from the National Science Museum, Tokyo. 5. Coenagrionidae, Protoneuridae and Platycnemididae. Bulletin of the National Science Museum, Series A Zoology 23: 17-34.

Bui H.M. 2007. Danh lục bằng hình ảnh các loài chuồn chuồn Phú Quốc [Approximate translation: "Photographic Checklist of Damselflies and Dragonflies of Phu Quoc Island"]. Wildlife At Risk Published as a book. Wildlife At Risk, Vietnam. [In Vietnamese.] Available from http://wildlifeatrisk.org/2019/01/28/photographic-checklist-of-damselflies-and-dragonflies-of-phuquoc-2008-vietnamese/ [accessed 2 Dec. 2019].

Cowley J. 1934. Changes in the generic names of the Odonata. Entomologist 67: 200-205.

Cowley J. 1936. LIII. - The Disparoneura complex: generic characters and lists of species (Odonata). Annals and Magazine of Natural History 10: 509-526. https://doi.org/10.1080/00222933608655150 
Dijkstra K.D.B., Kalman V.J., Dow R.A., Stokvis F.R. \& van Tol J. 2014. Redefining the damselfly families: a comprehensive molecular phylogeny of Zygoptera (Odonata). Systematic Entomology 39: 68-96. https://doi.org/10.1111/syen.12035

Do M.C. \& Dang T.T.H. 2007. Checklist of Dragonfly from Vietnam. Vietnam National University, Hanoi.

Do M.C., Bui H.M. \& Nguyen V.K. 2011. Dragonflies of Phu Quoc Island, South Vietnam. Agrion 15: $54-57$.

Kompier T. 2019. Dragonflies and Damselflies of Vietnam. Available from http://odonatavietnam.blogspot.com/search/label/Prodasineura [accessed 1 Oct. 2019.]

Kosterin O.E. 2015. Prodasineura hoffmanni sp. nov. (Odonata, Platycnemididae, Disparoneurinae) from eastern Cambodia. Zootaxa 4027: 565-577. https://doi.org/10.11646/zootaxa.4027.4.6

Kosterin O.E. 2016. A survey of Odonata of Mondulkiri, the elevated eastern province of Cambodia, for ten days in June 2014. International Dragonfly Fund Report 98: 1-85.

Orr A.G. 2005. Dragonflies of Peninsular Malaysia and Singapore. Natural History Publications, Borneo.

Phan Q.T. \& Dinh T.P.A. 2016. Odonata from Cham Islands, off central Vietnam collected in September 2015. International Dragonfly Fund Report 13: 1-22.

Phan Q.T. \& Ngo Q.P. 2019. Checklist of damselflies (Odonata: Zygoptera) from Kon Ka Kinh National Park of the Central Highlands of Vietnam. Journal of the International Dragonfly Fund 133: 1-18.

Schorr M. \& Paulson D. 2019. World Odonata List. Available from http://www.pugetsound.edu/ academics/academic-resources/slater-museum/biodiversity-resources/dragonflies/world-odonata-list2/ [accessed 1 Oct. 2019].

von Ellenrieder N., Hauser M., Gaimari S.D. \& Pham H.T. 2015. First records of Macromia katae (Macromiidae) and Indothemis carnatica (Libellulidae) from Vietnam (Insecta: Odonata). Checklist 11: 1-13. https://doi.org/10.15560/11.1.1514

Yokoi N. \& Souphanthong V. 2014. A list of Lao Dragonflies. Kyoei Printing Co. Ltd, Koriyama.

Manuscript received: 4 October 2019

Manuscript accepted: 12 March 2020

Published on: 22 May 2020

Topic editor: Nesrine Akkari

Desk editor: Jeroen Venderickx

Printed versions of all papers are also deposited in the libraries of the institutes that are members of the EJT consortium: Muséum national d'histoire naturelle, Paris, France; Meise Botanic Garden, Belgium; Royal Museum for Central Africa, Tervuren, Belgium; Royal Belgian Institute of Natural Sciences, Brussels, Belgium; Natural History Museum of Denmark, Copenhagen, Denmark; Naturalis Biodiversity Center, Leiden, the Netherlands; Museo Nacional de Ciencias Naturales-CSIC, Madrid, Spain; Real Jardín Botánico de Madrid CSIC, Spain; Zoological Research Museum Alexander Koenig, Bonn, Germany; National Museum, Prague, Czech Republic. 